Article

\title{
The Short-Term Effects of Rice Straw Biochar, Nitrogen and Phosphorus Fertilizer on Rice Yield and Soil Properties in a Cold Waterlogged Paddy Field
}

\author{
Linlin $\mathrm{Si}^{1,2} \mathbb{D}^{\mathbb{D}}$, Yinan Xie ${ }^{1,2}$, Qingxu Ma ${ }^{1,2}$ and Lianghuan $\mathrm{Wu}^{1,2,3, *}$ \\ 1 Zhejiang Provincial Key Laboratory of Agricultural Resource and Environment, College of Environmental \\ and Resource Sciences, Zhejiang University, Hangzhou 310058, China; sdarling2011@163.com (L.S.); \\ yinanxie0510@hotmail.com (Y.X.); ma901220@163.com (Q.M.) \\ 2 Ministry of Education Key Laboratory of Environmental Remediation and Ecosystem Health, \\ College of Environmental and Resource Sciences, Zhejiang University, Hangzhou 310058, China \\ 3 State Key Laboratory of Nutrition Resources Integrated Utilization, Kingenta Ecological Engineering \\ Group Co., Ltd., Linyi 276000, Shandong, China \\ * Correspondence: finm@zju.edu.cn; Tel.: +86-571-889-82922
}

Received: 8 December 2017; Accepted: 13 February 2018; Published: 17 February 2018

\begin{abstract}
Crop productivity in cold waterlogged paddy fields can be constrained by chronic flooding stress and low temperature. Farmers typically use chemical fertilizer to improve crop production, but this conventional fertilization is not very effective in a cold waterlogged paddy field. Biochar amendment has been proposed as a promising management approach to eliminating these obstacles. However, little is known about the performance of biochar when combined with $\mathrm{N}$ fertilizer and $\mathrm{P}$ fertilizer in cold waterlogged soils. The aim of this study was, therefore, to assess the main effects and interactive effects of rice straw biochar, $\mathrm{N}$ and $\mathrm{P}$ fertilizer on rice growth and soil properties in a cold waterlogged paddy field. The field treatments consisted of a factorial combination of two biochar levels $\left(0\right.$ and $\left.2.25 \mathrm{t} \mathrm{ha}^{-1}\right)$, two $\mathrm{N}$ fertilizer levels (120.0 and $\left.180.0 \mathrm{~kg} \mathrm{ha}^{-1}\right)$ and two $P$ fertilizer levels ( 37.5 and $67.5 \mathrm{~kg} \mathrm{ha}^{-1}$ ) which were arranged in a randomized block design, with three replicates. Results confirmed that biochar application caused a significant increase in the soil $\mathrm{pH}$ due to its liming effect, while this application resulted in a significant decrease in soil exchangeable cations, such as exchangeable $\mathrm{Ca}, \mathrm{Mg}, \mathrm{Al}$ and base cations. The interactive effect of $\mathrm{N}$ fertilizer, $\mathrm{P}$ fertilizer and biochar was significant for soil total N. Moreover, a negative effect of biochar on the internal K use efficiency suggested that $\mathrm{K}$ uptake into rice may benefit from biochar application. According to the partial Eta squared values, the combined application of $\mathrm{N}$ fertilizer and biochar was as effective as pure $\mathrm{P}$ fertilization at increasing straw $\mathrm{P}$ uptake. The addition of biochar to farmers' fertilization practice treatment $\left(180.0 \mathrm{~kg} \mathrm{~N} \mathrm{ha}^{-1}, 67.5 \mathrm{~kg} \mathrm{P}_{2} \mathrm{O}_{5} \mathrm{ha}^{-1}\right.$ and $\left.67.5 \mathrm{~kg} \mathrm{~K}_{2} \mathrm{O} \mathrm{ha}^{-1}\right)$ significantly increased rice yield, mainly owing to improvements in grains per panicle. However, notable effects of biochar on rice yield and biomass production were not detected. More studies are required to assess the long-term behavior of biochar in a cold waterlogged paddy field. This study may lay a theoretical foundation for blended application of biochar with fertilizer in a cold waterlogged paddy field.
\end{abstract}

Keywords: biochar; fertilizer; cold waterlogged paddy; rice yield; soil properties

\section{Introduction}

Cold waterlogged paddy fields are a type of farmland with low productivity due to chronic stress from flooding [1]. In China, the fields are distributed mainly in the south of the country with an area of about 3.5 million ha, which occupies almost $50 \%$ of the low-yield paddy field area and $15 \%$ of the total paddy field area [2]. Due to the fact that excessive water continuously remains in 
cold waterlogged paddy fields, their soils are generally characterized by negative properties, such as relatively low temperature, damaging aggregates, deficiency of available nutrients and accumulation of reducing substances, which ultimately reduce crop production [3]. However, these soils readily accumulate organic matter because of the increasing number of soil anaerobic microorganism [4]. Obviously, proper agronomic practice, especially in simple and low-cost ways, can be used eliminate these obstacle factors, thus there is a need to manage waterlogged soils to increase crop production.

Rice (Oryza sativa L.) is the world's most important staple food; it can support more than half of the world's population [5]. Global rice production in 2016 was up to about 749 million $t$, superseded by maize with a yield of 959 million $t$ [6]. According to data from the National Bureau of Statistics of China, a total area of approximately 30,178 thousand ha was covered by rice, which produced 207 million $t$ of grain in 2016 [7]. Nowadays, it is therefore crucial to boost rice yield in limited cultivated land area per capita to meet the food demands of the increasing worldwide population. Several alternative counter-measures, including developing water conservancy projects, ameliorating soil qualities, popularizing techniques of plant protection and cultivation as well as the application of fertilizers have been implemented [8]. The application of fertilizer is of importance for maintaining high crop yield. China's fertilizer use was $330 \mathrm{t}$ in 1961; it reached 26,000 $\mathrm{t}$ in 2009 [9]. However, the nutrient use efficiency in China, especially $\mathrm{N}$ fertilizer and $\mathrm{P}$ fertilizer, was relatively low compared to European countries and the US [10]. The combination of inefficiency and excess fertilizer use has adverse impacts on water, soil, climate and biodiversity [11]. Hence, the Chinese Ministry of Agriculture approved a "Zero Growth Action Plan", which declares that the annual growth in the use of total fertilizer will be regulated to remain below 1\% from 2015 to 2019, with zero increase from 2020 [12]. The output of straw rose inevitably as the main crop harvested annually. Recently, the Chinese Government has encountered the issue of how to effectively dispose of the crop residues, which are generally burned in the fields after harvest. Thus, these residues cause or aggravate air pollution, such as haze [13].

One promising management approach is to convert rice straw into biochar $[14,15]$. Being intended specifically for agronomic and environmental purposes, biochar is the carbon-rich product derived from thermal degradation of biomass under air-starved conditions [16]. It has been proved to alter the physical and chemical properties as well as the biological process of soil due to its physical characteristics, such as large surface area and porous structure [17]. According to Burrell et al., the addition of biochar can affect the physical properties of soil via indirect and direct means [18]. Previous studies have indicated that the incorporation of biochar can improve the water holding capacity of sandy soil, which might be beneficial for the water utilization of plants [19]. Similarly, the chemical properties of soil can also be influenced by the addition of biochar in a more complex way due to the extensive impact of biochar on soil chemistry [20]. Biochar has been shown to increase soil nutrient availability by heightening $\mathrm{pH}$ in an acidic soil environment or absorption of more cations [21]. However, negative responses to soil quality and crop yield were also observed in the presence of biochar [22].

Generally, rice straw biochar is alkaline, regardless of pyrolysis temperature and residence time [23]. Alkaline biochar can be used as a soil amendment for neutralizing acidity, improving soil fertility and sequestering $C$ in acidic soils [24]. Dong et al. demonstrated that rice straw biochar enhanced rice production and nitrogen retention in a waterlogged paddy field [25]. Cui et al. found a significant reduction in $\mathrm{CH}_{4}$ emissions, global warming potential and greenhouse gas intensity when a cold waterlogged paddy field was applied with at least $2 \mathrm{tha}^{-1}$ rice straw biochar in North China [26]. It appears that a cold waterlogged paddy field may benefit from rice straw biochar amendment.

Previous studies indicated that the combined application of biochar and fertilizer had a better performance than either alone, in terms of soil properties and crop yield. [27]. However, few studies have been conducted to analyze the interactive effects of biochar and fertilizer in cold waterlogged paddy fields. This restricts the development of biochar in the environment of waterlogged stress, especially when combined with multiple element fertilizers. Therefore, this study investigated the 
effects of rice straw biochar, $\mathrm{N}$ fertilizer, $\mathrm{P}$ fertilizer and their interactions on soil properties and crop performance in a cold waterlogged paddy field in 2015.

\section{Materials and Methods}

\subsection{Biochar for Soil Amendment}

The biochar used for the field experiment was supplied by Nanjing Qinfeng Crop Straw Technology Co., in Nanjing China. The commercial rice straw biochar was produced via pyrolysis from rice straw at temperatures of $550-650{ }^{\circ} \mathrm{C}$ with a residence time of about $1 \mathrm{~h}$ under an oxygen-limited atmosphere. The bulk biochars were milled to pass through a 2-mm sieve, before being homogenized thoroughly. The $\mathrm{pH}$ and electrical conductivity of biochar were determined using suspension with distilled $\mathrm{H}_{2} \mathrm{O}$ at a biochar/water ratio of 1:20 $(w / v)$. The ultimate analysis of biochar was performed using an elemental analyzer (Vario EL CUBE, Elementar, Langenselbold, Germany). After published wet digestion, the total $\mathrm{P}$ and $\mathrm{K}$ of biochar were measured by inductively coupled plasma-mass spectroscopy (G3271A, Shimadzu, Kyoto, Japan) [28]. Table 1 shows the basic properties of biochar used in the field.

Table 1. Characteristics of soil and biochar in the study.

\begin{tabular}{cccc}
\hline Parameter & Unit & Biochar & Soil \\
\hline $\mathrm{pH}$ & & 9.71 & 5.06 \\
$\mathrm{EC}$ & $\mu \mathrm{S} \mathrm{cm}^{-1}$ & 3547.87 & 99.86 \\
$\mathrm{CEC}$ & $\mathrm{cmol} \mathrm{kg}^{-1}$ & $\mathrm{nd}$ & 7.48 \\
$\mathrm{OM}$ & $\mathrm{g} \mathrm{kg}^{-1}$ & $\mathrm{nd}$ & 34.61 \\
$\mathrm{TC}$ & $\mathrm{g} \mathrm{kg}^{-1}$ & 442.68 & $\mathrm{nd}$ \\
$\mathrm{TH}$ & $\mathrm{g} \mathrm{kg}^{-1}$ & 9.42 & $\mathrm{nd}$ \\
$\mathrm{TS}$ & $\mathrm{g} \mathrm{kg}^{-1}$ & 2.44 & $\mathrm{nd}$ \\
$\mathrm{TN}$ & $\mathrm{g} \mathrm{kg}^{-1}$ & 6.35 & 1.63 \\
$\mathrm{AN}$ & $\mathrm{mg} \mathrm{kg}^{-1}$ & $\mathrm{nd}$ & 122.41 \\
$\mathrm{TP}$ & $\mathrm{g} \mathrm{kg}^{-1}$ & 0.92 & $\mathrm{nd}$ \\
$\mathrm{AP}$ & $\mathrm{mg} \mathrm{kg}^{-1}$ & $\mathrm{nd}$ & 5.98 \\
$\mathrm{TK}$ & $\mathrm{g} \mathrm{kg}^{-1}$ & 28.15 & $\mathrm{nd}$ \\
$\mathrm{AK}$ & $\mathrm{mg} \mathrm{kg}^{-1}$ & nd & 42.80 \\
\hline
\end{tabular}

Notes: EC: Electrical conductivity; CEC: Cation exchange capacity; OM: Organic matter; TC: Total C; TH: Total H; TS: Total S; TN: Total N; AN: Available N; TP: Total P; AP: Available P; TK: Total K; AK: Available K; and nd: not determined.

\subsection{Experimental Site}

The experimental site was established at $30^{\circ} 40^{\prime} \mathrm{N}$ and $119^{\circ} 87^{\prime} \mathrm{E}$ in Xiaogucheng Village, Jingshan Town, Hangzhou City, Zhejiang, China. Located in the Yangtze River Delta, this region is characterized by a typical subtropical monsoon climate with a total precipitation of $1789.5 \mathrm{~mm}$ and a mean temperature of $17.6{ }^{\circ} \mathrm{C}$ in the year of 2015 (Figure 1). The surface texture of the soil from a cold waterlogged paddy field was identified as silt loam with percentages of sand, silt, and clay of 10, 66 and $24 \%$, respectively. The basic properties of the topsoil $(0-15 \mathrm{~cm})$ prior to the experiment are shown in Table 1. 


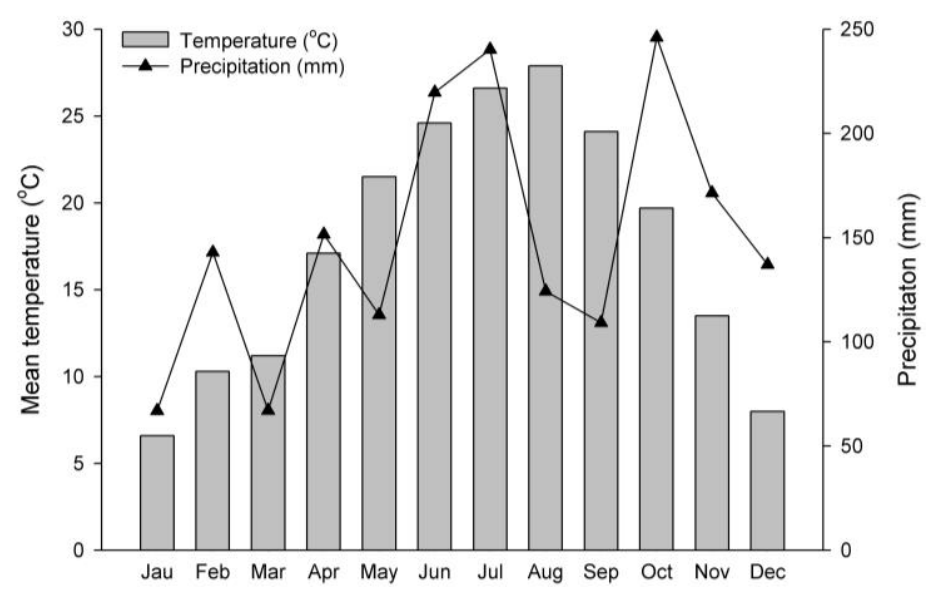

Figure 1. Monthly mean temperature and precipitation for the crop growing season in 2015. Figure based on public data from Meteorological Bureau of Zhejiang Province (2015) [29].

\subsection{Experimental Setup}

The field trail was conducted by employing a randomized block design, which consists of eight plots that all had dimensions of $3 \mathrm{~m} \times 6 \mathrm{~m}$ with three replicates. Individual plots were separated by plastic film-covered ridges within rows, while corridors were left between rows. Guard rows of rice without fertilization were set around the perimeter of the trail to prevent border effects.

The treatments were factorial combinations of two $\mathrm{N}$ fertilizer levels $\left(\mathrm{N}_{1}=120.0 \mathrm{~kg} \mathrm{~N} \mathrm{ha}^{-1}\right.$ and $\left.\mathrm{N}_{2}=180.0 \mathrm{~kg} \mathrm{~N} \mathrm{ha}^{-1}\right)$, two $\mathrm{P}$ fertilizer levels $\left(\mathrm{P}_{1}=37.5 \mathrm{~kg} \mathrm{P}_{2} \mathrm{O}_{5} \mathrm{ha}^{-1}\right.$ and $\left.\mathrm{P}_{2}=67.5 \mathrm{~kg} \mathrm{P}_{2} \mathrm{O}_{5} \mathrm{ha}^{-1}\right)$ and two biochar levels $\left(\mathrm{B}_{0}=0 \mathrm{t}\right.$ biochar ha ${ }^{-1}$ and $\mathrm{B}_{1}=2.25 \mathrm{t}$ biochar ha $\left.{ }^{-1}\right)$. Application rates of biochar and fertilizer for each treatment are presented in Table 2. As the farmers' fertilization practice, $\mathrm{N}_{2} \mathrm{P}_{2} \mathrm{~B}_{0}$ treatment received $180.0 \mathrm{~kg} \mathrm{~N} \mathrm{ha}^{-1}, 67.5 \mathrm{~kg} \mathrm{P}_{2} \mathrm{O}_{5} \mathrm{ha}^{-1}$ and $67.5 \mathrm{~kg} \mathrm{P}_{2} \mathrm{O}_{5} \mathrm{ha}^{-1}$. $\mathrm{N}$ fertilizer, $\mathrm{P}$ fertilizer and $\mathrm{K}$ fertilizer were applied in the form of urea $(46 \% \mathrm{~N})$, fused magnesium phosphate $\left(12 \% \mathrm{P}_{2} \mathrm{O}_{5}\right)$ and potassium chloride $\left(60 \% \mathrm{~K}_{2} \mathrm{O}\right)$, respectively. Prior to transplanting in June, all dry biochar and $\mathrm{P}$ fertilizer were spread on the topsoil and were incorporated into the top $0.15 \mathrm{~m}$ of soil with a cultivator. Sixty percent of $\mathrm{N}$ fertilizer and $\mathrm{K}$ fertilizer were applied deeply as a basal fertilizer before transplanting in June, while the remaining forty percent were applied as dressing during the booting stage in August.

Table 2. Details of treatments in the cold waterlogged paddy field experiment.

\begin{tabular}{|c|c|c|c|c|}
\hline \multirow{2}{*}{ Treatment } & $\mathbf{N}$ & $\mathrm{P}_{2} \mathrm{O}_{5}$ & $\mathrm{~K}_{2} \mathrm{O}$ & Biochar \\
\hline & $\left(\mathrm{kg} \mathrm{ha}^{-1}\right)$ & $\left(\mathrm{kg} \mathrm{ha}^{-1}\right)$ & $\left(\mathrm{kg} \mathrm{ha}^{-1}\right)$ & $\left(t h^{-1}\right)$ \\
\hline $\mathrm{N}_{1} \mathrm{P}_{1} \mathrm{~B}_{0}$ & 120.0 & 37.5 & 67.5 & 0 \\
\hline $\mathrm{N}_{1} \mathrm{P}_{1} \mathrm{~B}_{1}$ & 120.0 & 37.5 & 67.5 & 2.25 \\
\hline $\mathrm{N}_{1} \mathrm{P}_{2} \mathrm{~B}_{0}$ & 120.0 & 67.5 & 67.5 & 0 \\
\hline $\mathrm{N}_{1} \mathrm{P}_{2} \mathrm{~B}_{1}$ & 120.0 & 67.5 & 67.5 & 2.25 \\
\hline $\mathrm{N}_{2} \mathrm{P}_{1} \mathrm{~B}_{0}$ & 180.0 & 37.5 & 67.5 & 0 \\
\hline $\mathrm{N}_{2} \mathrm{P}_{1} \mathrm{~B}_{1}$ & 180.0 & 37.5 & 67.5 & 2.25 \\
\hline $\mathrm{N}_{2} \mathrm{P}_{2} \mathrm{~B}_{0}$ (Farmers' fertilization practice) & 180.0 & 67.5 & 67.5 & 0 \\
\hline $\mathrm{N}_{2} \mathrm{P}_{2} \mathrm{~B}_{1}$ & 180.0 & 67.5 & 67.5 & 2.25 \\
\hline
\end{tabular}

Notes: $\mathrm{N}_{1}$ : $120.0 \mathrm{~kg} \mathrm{~N} \mathrm{ha}^{-1} ; \mathrm{N}_{2}: 180.0 \mathrm{~kg} \mathrm{~N} \mathrm{ha}^{-1} ; \mathrm{P}_{1}: 37.5 \mathrm{~kg} \mathrm{P}_{2} \mathrm{O}_{5} \mathrm{ha}^{-1} ; \mathrm{P}_{2}: 67.5 \mathrm{~kg} \mathrm{P}_{2} \mathrm{O}_{5} \mathrm{ha}^{-1} ; \mathrm{B}_{0}: 0 \mathrm{tha}^{-1}$; $\mathrm{B}_{1}: 2.25 \mathrm{tha}^{-1}$.

The rice (Jia 58) was sown during late May, before being harvested in early November. Rice seedlings were transplanted to the paddy fields two weeks after sowing with a row spacing of $30 \mathrm{~cm}$ and a plant spacing of $15 \mathrm{~cm}$. Alternative wetting and drying irrigation was adopted to manage water 
regime in rice production [30]. Pesticides for controlling weeds, insect damage and diseases were applied consistently across all plots.

\subsection{Soil Sampling and Analysis}

Five soil cores were sampled randomly from the $0-15 \mathrm{~cm}$ soil layer of each plot after rice harvest, before being mixed thoroughly to form a composite sample. All samples were transported immediately to the lab prior to removal of plant residues and detritus. Fresh samples were ground and passed through a 2-mm sieve for ammonia and nitrate analysis. Another portion of these samples was air-dried at ambient temperature, ground and passed through a 2-mm sieve, before being processed through a $0.15-\mathrm{mm}$ sieve for further analysis.

Soil water content was determined by drying the sample at $105{ }^{\circ} \mathrm{C}$ until there was no more weight loss [31]. The $\mathrm{pH}$ of the soil sample was measured in distilled water $(1: 2.5, w / v)$ with a $\mathrm{pH}$ meter (FE20, Mettler Toledo, Shanghai, China). For electrical conductivity analysis, $20.0 \mathrm{~g}$ of soil was shaken with $100 \mathrm{~mL}$ of distilled water for $0.5 \mathrm{~h}$, before standing for another $0.5 \mathrm{~h}$ at room temperature. The supernatant was measured using a conductivity meter (DDS-307, INESA, Shanghai, China). The soil organic matter content was determined by the $\mathrm{K}_{2} \mathrm{Cr}_{2} \mathrm{O}_{7}-\mathrm{H}_{2} \mathrm{SO}_{4}$ oxidation method. Determination of cation exchange capacity (CEC) and exchangeable base cations (EBC) were carried out at a $\mathrm{pH}$ of 7.0 with $1 \mathrm{M} \mathrm{NH}_{4} \mathrm{OAc}[32,33]$. The leachate was subsequently analyzed by inductively coupled plasma-mass spectroscopy (G3271A, Shimadzu, Kyoto, Japan). The exchangeable acidity and exchangeable $\mathrm{H}$ of the soil sample was extracted using $1 \mathrm{M} \mathrm{KCl}$ and titrated against $0.02 \mathrm{M} \mathrm{NaOH}$, respectively [34]. The difference between exchangeable acidity and exchangeable $\mathrm{H}$ is exchangeable $\mathrm{Al}$ (EAl). Total $\mathrm{N}(\mathrm{TN})$ was determined by the semimicro-Kjeldahl method, while available $\mathrm{N}$ was determined by the alkali hydrolysis diffusion method [35]. $\mathrm{NO}_{3}{ }^{-}-\mathrm{N}$ and $\mathrm{NH}_{4}{ }^{+}-\mathrm{N}$ from fresh soil were extracted with $2 \mathrm{M} \mathrm{KCl}(1: 10, w / v)$, before being determined using a spectrophotometer (TU1810, Persee, Shanghai, China) [36]. Available P (AP) was lixiviated with $\mathrm{HCl}-\mathrm{NH}_{4} \mathrm{~F}$ extractant $(1: 10, w / v)$ and estimated by molybdenum blue colorimetry [37]. Available K (AK) was extracted with $1 \mathrm{M}$ $\mathrm{NH}_{4} \mathrm{OAc}(1: 10, w / v)$ and analyzed using a flame photometer (FP6410, INESA, Shanghai, China) [38].

\subsection{Rice Sampling and Analysis}

Five representative plants were collected from each plot on August 9 (tillering), August 24 (booting), September 9 (heading) and November 6 (maturity) in 2015. All the plants were rinsed with tap water, before being subjected to drying at $105^{\circ} \mathrm{C}$ for $30 \mathrm{~min}$. This temperature was decreased to $75^{\circ} \mathrm{C}$ and the drying continued until no more weight loss was observed. Subsequently, the plants were weighed to determine the weight of dry matter. Before the final harvest, the yield components of rice were determined, including effective panicles, grains per panicle, filled grain percentage and thousand-grain weight. Grain yields were determined by manually harvesting the whole plants in a single plot and were recorded on a $15 \%$ moisture content basis.

After oven-drying, the samples of straw and grain were finely ground into powder to pass through a $0.25-\mathrm{mm}$ sieve. For further element analysis, $300 \mathrm{mg}$ of the ground material was digested with concentrated sulfuric acid and $\mathrm{H}_{2} \mathrm{O}_{2}$. Plant $\mathrm{N}$ content was analyzed by distilling the $\mathrm{NH}_{3}$ from the digested material [39]. Plant $\mathrm{P}$ and $\mathrm{K}$ concentration was quantified by the molybdenum blue color method and flame photometry, respectively [40]. The nutrient uptake of different tissues was calculated by multiplying the nutrient concentration by the corresponding tissue biomass. Total nutrient uptake was the sum of straw nutrient uptake and grain nutrient uptake. Internal nutrient use efficiency and partial nutrient productivity were calculated with the grain yield divided by the total nutrient uptake and applied nutrient rate, respectively.

\subsection{Data Analysis}

A multiple factor analysis of variance (ANOVA) was performed using fixed factors, including $\mathrm{N}$ rate, $\mathrm{P}$ rate and biochar rate as well as a block. Effect size was calculated by partial Eta squared. 
Single-factor ANOVA was employed to determine differences between treatments. The least significant difference (LSD) multiple comparison was conducted at a significance level of $5 \%$. Data analysis was assessed with SPSS 13.0 software. Figures were drawn using SigmaPlot 10.0 software.

\section{Results}

\subsection{Crop Yield, Yield Components and Biomass Production}

Influences of N, P fertilizer and biochar on rice yield and yield components are shown in Table 3. Changing biochar had varying effects on the rice yield relative to corresponding treatments containing fertilizer alone in a cold waterlogged paddy field. The $\mathrm{N}_{2} \mathrm{P}_{2} \mathrm{~B}_{0}$ obtained the lowest rice yield at an average of $6.0 \mathrm{t} \mathrm{ha}^{-1}$ in all treatments. Dramatically, the highest rice yield was recorded from the addition of $\mathrm{N}_{2} \mathrm{P}_{2} \mathrm{~B}_{1}$, with a marked yield boost of $33 \%$ compared to the relevant biochar-absent treatment. No significant difference was observed in the grain yield between the other six treatments, which had relatively low rates of $\mathrm{N}$ and $\mathrm{P}$ simultaneously. However, in comparison with only application of $\mathrm{N}$ and $\mathrm{P}$ fertilizer, the corresponding treatments combined with biochar resulted in moderate decrements in yield of $13.3 \%, 14.1 \%$ and $9.5 \%$, respectively. Similarly, $\mathrm{N}_{1} \mathrm{P}_{1} \mathrm{~B}_{1}, \mathrm{~N}_{1} \mathrm{P}_{2} \mathrm{~B}_{1}$ and $\mathrm{N}_{2} \mathrm{P}_{1} \mathrm{~B}_{1}$ had lower grains per panicle compared to $\mathrm{N}_{1} \mathrm{P}_{1} \mathrm{~B}_{0}, \mathrm{~N}_{1} \mathrm{P}_{2} \mathrm{~B}_{0}$ and $\mathrm{N}_{2} \mathrm{P}_{1} \mathrm{~B}_{0}$, respectively, while $\mathrm{N}_{2} \mathrm{P}_{2} \mathrm{~B}_{1}$ yielded significantly higher grains per panicle than $\mathrm{N}_{2} \mathrm{P}_{2} \mathrm{~B}_{0}, \mathrm{~N}_{1} \mathrm{P}_{2} \mathrm{~B}_{0}$ and $\mathrm{N}_{1} \mathrm{P}_{2} \mathrm{~B}_{1}$. Effective panicles and harvest index did not differ significantly between any treatments, being in the range of 2.94-3.30 $\times 10^{6} \mathrm{ha}^{-1}$ and $44.8-48.8 \%$, respectively. The filled grain percentage from $\mathrm{N}_{2} \mathrm{P}_{2} \mathrm{~B}_{0}$ was significantly lower than that from $\mathrm{N}_{1} \mathrm{P}_{2} \mathrm{~B}_{1}$, which had the highest filled grain percentage of $72.7 \%$. Compared to $\mathrm{N}_{1} \mathrm{P}_{1} \mathrm{~B}_{1}$, a significant decline in the thousand-grain weight at a rate of $4.4 \%$ emerged in the $\mathrm{N}_{2} \mathrm{P}_{2} \mathrm{~B}_{1}$.

Table 3. Rice yield, yield components and harvest index under different treatments.

\begin{tabular}{ccccccc}
\hline \multirow{2}{*}{ Treatment } & Yield & $\begin{array}{c}\text { Effective } \\
\text { Panicles }\end{array}$ & $\begin{array}{c}\text { Grains Per } \\
\text { Panicle }\end{array}$ & $\begin{array}{c}\text { Filled Grain } \\
\text { Percentage }\end{array}$ & $\begin{array}{c}\text { Thousand-Grain } \\
\text { Weight }\end{array}$ & $\begin{array}{c}\text { Harvest } \\
\text { Index }\end{array}$ \\
\cline { 2 - 7 } & $\mathbf{( t ~ h \mathbf { ~ h a } ^ { - \mathbf { 1 } } )}$ & $\left(\times \mathbf{1 0}^{\mathbf{6}} \mathbf{h a}^{-\mathbf{1}}\right)$ & & $\mathbf{( \% )}$ & $\mathbf{( g )}$ & $\mathbf{( \% )}$ \\
\hline $\mathrm{N}_{1} \mathrm{P}_{1} \mathrm{~B}_{0}$ & $7.5 \mathrm{ab}$ & $3.08 \mathrm{a}$ & $126.9 \mathrm{ab}$ & $64.7 \mathrm{ab}$ & $26.0 \mathrm{ab}$ & $45.7 \mathrm{a}$ \\
$\mathrm{N}_{1} \mathrm{P}_{1} \mathrm{~B}_{1}$ & $6.5 \mathrm{ab}$ & $2.94 \mathrm{a}$ & $126.6 \mathrm{ab}$ & $62.9 \mathrm{ab}$ & $26.2 \mathrm{a}$ & $46.2 \mathrm{a}$ \\
$\mathrm{N}_{1} \mathrm{P}_{2} \mathrm{~B}_{0}$ & $7.8 \mathrm{ab}$ & $2.97 \mathrm{a}$ & $119.3 \mathrm{~b}$ & $64.1 \mathrm{ab}$ & $25.9 \mathrm{ab}$ & $45.5 \mathrm{a}$ \\
$\mathrm{N}_{1} \mathrm{P}_{2} \mathrm{~B}_{1}$ & $6.7 \mathrm{ab}$ & $3.00 \mathrm{a}$ & $119.1 \mathrm{~b}$ & $72.7 \mathrm{a}$ & $25.9 \mathrm{ab}$ & $48.8 \mathrm{a}$ \\
$\mathrm{N}_{2} \mathrm{P}_{1} \mathrm{~B}_{0}$ & $7.4 \mathrm{ab}$ & $3.30 \mathrm{a}$ & $126.6 \mathrm{ab}$ & $63.8 \mathrm{ab}$ & $25.9 \mathrm{ab}$ & $47.5 \mathrm{a}$ \\
$\mathrm{N}_{2} \mathrm{P}_{1} \mathrm{~B}_{1}$ & $6.7 \mathrm{ab}$ & $3.04 \mathrm{a}$ & $119.5 \mathrm{ab}$ & $61.9 \mathrm{ab}$ & $25.5 \mathrm{ab}$ & $46.3 \mathrm{a}$ \\
$\mathrm{N}_{2} \mathrm{P}_{2} \mathrm{~B}_{0}$ & $6.0 \mathrm{~b}$ & $3.24 \mathrm{a}$ & $114.1 \mathrm{~b}$ & $58.4 \mathrm{~b}$ & $25.8 \mathrm{ab}$ & $44.8 \mathrm{a}$ \\
$\mathrm{N}_{2} \mathrm{P}_{2} \mathrm{~B}_{1}$ & $8.0 \mathrm{a}$ & $3.24 \mathrm{a}$ & $137.3 \mathrm{a}$ & $66.7 \mathrm{ab}$ & $25.1 \mathrm{~b}$ & $47.0 \mathrm{a}$ \\
\hline
\end{tabular}

Notes: Different lowercase letters within one column indicate a significant difference $(p<5 \%)$.

Figure 2 illustrates the rice biomass in different growth periods under various rates of fertilizers with or without biochar. No significant difference was shown between the individual fertilizer treatment and corresponding fertilizer plus biochar treatment, except at the heading stage (Figure 2a-d). Moreover, statistical significance did not exist between any treatments during tillering and maturity stage (Figure $2 \mathrm{a}, \mathrm{d}$ ). At the heading stage, the rice biomass from $\mathrm{N}_{2} \mathrm{P}_{1} \mathrm{~B}_{0}$ substantially declined to the lowest value of $6.07 \mathrm{t} \mathrm{ha}^{-1}$ when combined with biochar application (Figure 2c). Meanwhile, rice biomass from $\mathrm{N}_{2} \mathrm{P}_{1} \mathrm{~B}_{1}$ was also lower than that from other treatments at maturity (Figure 2c). During the booting and maturity stages, the greatest rice biomass was found in $\mathrm{N}_{2} \mathrm{P}_{2} \mathrm{~B}_{1}$, demonstrating an unremarkable rise in the rice biomass at a rate of $29.4 \%$ and $20.0 \%$, respectively, compared to $\mathrm{N}_{2} \mathrm{P}_{2} \mathrm{~B}_{0}$ (Figure $2 \mathrm{~b}, \mathrm{~d}$ ). $\mathrm{N}_{2} \mathrm{P}_{1} \mathrm{~B}_{0}$ resulted in the highest rice biomass of $8.94 \mathrm{t} \mathrm{ha}^{-1}$ at the heading stage, while it had lowest rice biomass with $3.67 \mathrm{tha}^{-1}$ at the booting stage (Figure $2 \mathrm{~b}, \mathrm{c}$ ). 

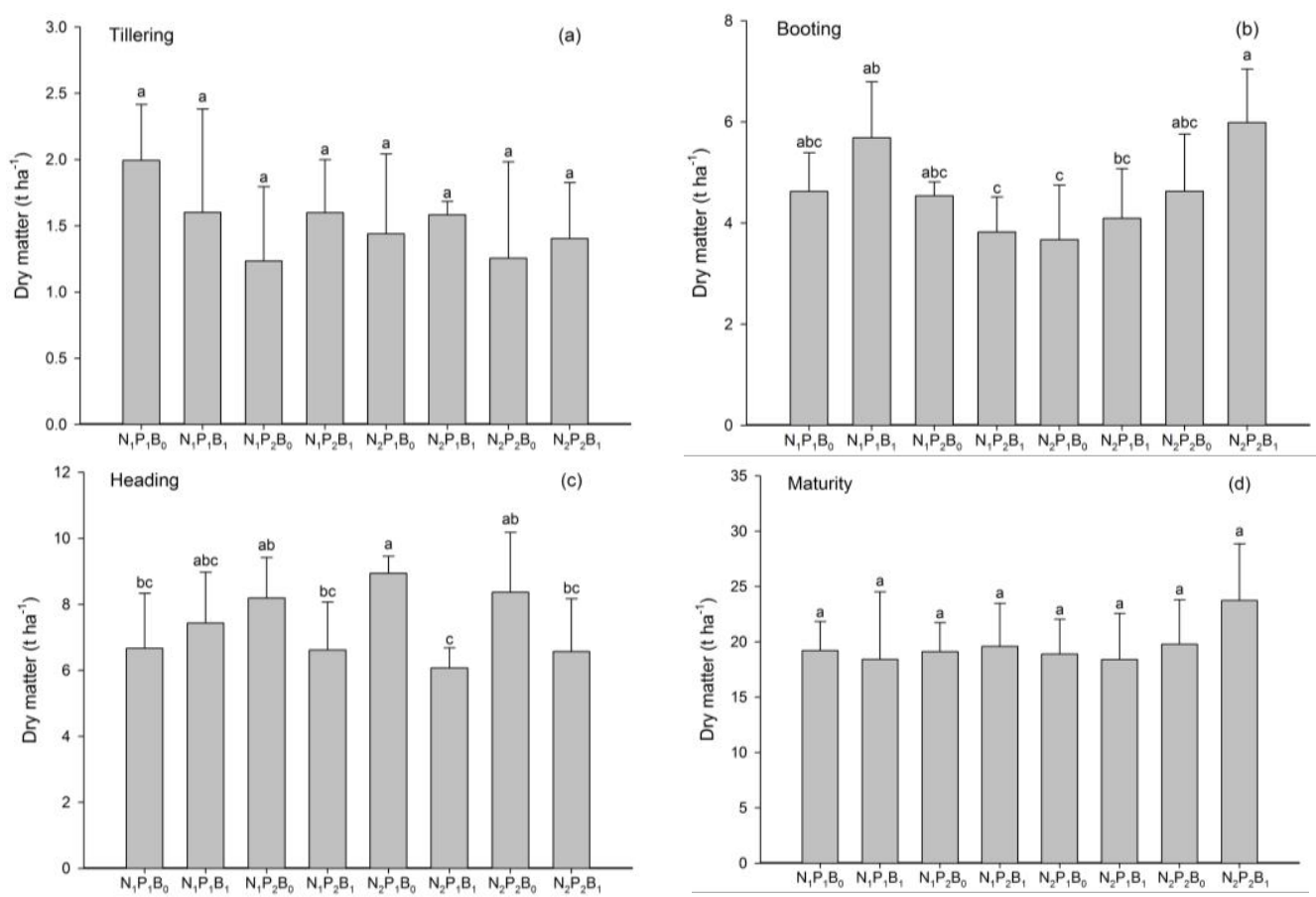

Figure 2. Effects of $\mathrm{N}$ and $\mathrm{P}$ application and biochar amendment on aboveground biomass production at the (a) tillering stage, (b) booting stage, (c) heading stage and (d) maturity stage. Different lowercase letters above bars indicate significant differences $(p<5 \%)$.

\subsection{Nutrient Use Efficiency, Concentration and Uptake}

Both grain $\mathrm{N}$ concentration and straw $\mathrm{N}$ concentration were not affected significantly by fertilizer, biochar or their interactions, varying from $0.91 \%$ in the $\mathrm{N}_{2} \mathrm{P}_{1} \mathrm{~B}_{1}$ to $1.03 \%$ in the $\mathrm{N}_{1} \mathrm{P}_{1} \mathrm{~B}_{1}$ and from $0.50 \%$ in the $\mathrm{N}_{1} \mathrm{P}_{2} \mathrm{~B}_{1}$ to $0.61 \%$ in the $\mathrm{N}_{2} \mathrm{P}_{2} \mathrm{~B}_{0}$, respectively (Table 4). Higher amounts of $\mathrm{P}$ addition obviously promoted $\mathrm{N}$ uptake into the grain when combined with $\mathrm{N}_{2}$ and biochar, although this was not seen in straw. The uptake of $\mathrm{N}$ to grain and straw ranged from $77.7-110.0$ and $38.4-56.8 \mathrm{~kg} \mathrm{~N} \mathrm{ha}^{-1}$, respectively, with the highest for both being from the $\mathrm{N}_{2} \mathrm{P}_{2} \mathrm{~B}_{1}$ and the lowest for both being from the $\mathrm{N}_{2} \mathrm{P}_{1} \mathrm{~B}_{1}$. As a result of the higher uptake of $\mathrm{N}$ into grain and straw, the average values of TN uptake by rice notably increased from $116.1 \mathrm{~kg} \mathrm{~N}^{-1}$ in $\mathrm{N}_{2} \mathrm{P}_{1} \mathrm{~B}_{1}$ to $166.8 \mathrm{~kg} \mathrm{~N}^{-1}$ in $\mathrm{N}_{2} \mathrm{P}_{2} \mathrm{~B}_{1}$. Like the $\mathrm{N}$ uptake by grain, the TN uptake into rice was comparable for the other treatments. The internal $\mathrm{N}$ use efficiency exhibited no obvious variation in the mean values, which was between 65.8 and $74.1 \mathrm{~kg} \mathrm{~kg}^{-1}$. The $\mathrm{N}$ partial factor productivity $\left(\mathrm{PFP}_{\mathrm{N}}\right)$ was significantly $(p<1 \%)$ decreased by $29.4 \%$ in response to $\mathrm{N}$ fertilization (Table 8). $\mathrm{N}_{2} \mathrm{P}_{1} \mathrm{~B}_{0}, \mathrm{~N}_{2} \mathrm{P}_{1} \mathrm{~B}_{1}, \mathrm{~N}_{2} \mathrm{P}_{2} \mathrm{~B}_{0}$ and $\mathrm{N}_{2} \mathrm{P}_{2} \mathrm{~B}_{0}$ significantly decreased $\mathrm{PFP}_{\mathrm{N}}$ by $31.7 \%$, $32.2 \%, 32.8 \%$ and $21.8 \%$, respectively, compared to $\mathrm{N}_{1} \mathrm{P}_{1} \mathrm{~B}_{0}, \mathrm{~N}_{1} \mathrm{P}_{1} \mathrm{~B}_{1}, \mathrm{~N}_{1} \mathrm{P}_{2} \mathrm{~B}_{0}$ and $\mathrm{N}_{1} \mathrm{P}_{2} \mathrm{~B}_{0}$.

Unlike grain $\mathrm{N}$ concentration, there was an obvious difference in grain $\mathrm{P}$ concentration between $\mathrm{N}_{1} \mathrm{P}_{1} \mathrm{~B}_{0}$ and $\mathrm{N}_{2} \mathrm{P}_{2} \mathrm{~B}_{1}$, which dropped from $0.288 \%$ to $0.256 \%$ (Table 5). Straw P concentration (SPC) responded significantly $(p<5 \%)$ to the $\mathrm{N}$ fertilizer with biochar interactions (Table 8). The highest SPC was derived from $\mathrm{N}_{2} \mathrm{P}_{2} \mathrm{~B}_{1}$, with pronounced increments of $17.7 \%, 20.2 \%$ and $21.5 \%$, compared to $\mathrm{N}_{2} \mathrm{P}_{1} \mathrm{~B}_{1}, \mathrm{~N}_{1} \mathrm{P}_{2} \mathrm{~B}_{1}$, and $\mathrm{N}_{2} \mathrm{P}_{1} \mathrm{~B}_{0}$, respectively. $\mathrm{P}$ uptake to grain was more or less equal, fluctuating between 22.2 and $29.1 \mathrm{~kg} \mathrm{P}^{-1}$. However, straw P uptake (SPU) responded significantly $(p<5 \%)$ to $\mathrm{P}$ fertilizer alone and $\mathrm{N}$ fertilizer with biochar interaction (Table 8 ). The $\mathrm{P}$ fertilizer resulted in a $14.9 \%$ increase in the SPU. The average mean of SPU significantly increased from $6.7 \mathrm{~kg} \mathrm{P} \mathrm{ha}^{-1}$ in $\mathrm{N}_{2} \mathrm{P}_{1} \mathrm{~B}_{0}$ to $11.0 \mathrm{~kg} \mathrm{P}$ ha ${ }^{-1}$ in $\mathrm{N}_{2} \mathrm{P}_{2} \mathrm{~B}_{1}$, due to a remarkably higher $\mathrm{P}$ concentration in the straw. The addition of biochar to the corresponding fertilizer had no significant effects on total $\mathrm{P}$ uptake, except a significant growth of $31.9 \%$ in $\mathrm{P}$ uptake by rice when biochar was combined with $\mathrm{N}_{2} \mathrm{P}_{2} \mathrm{~B}_{0}$. On the basis of $\mathrm{N}_{1} \mathrm{P}_{1} \mathrm{~B}_{0}$, increasing the $\mathrm{N}$ application rate to $180.0 \mathrm{~kg} \mathrm{ha}^{-1}$ was obviously beneficial for 
internal $\mathrm{P}$ use efficiency, which was in the range of $261.6-292.8 \mathrm{~kg} \mathrm{~kg}^{-1}$. P partial factor productivity $\left(\mathrm{PFP}_{\mathrm{P}}\right)$ declined significantly $(p<1 \%)$ in response to $\mathrm{P}$ fertilizer application, regardless of $\mathrm{N}$ fertilizer or biochar application (Table 8). The increase of $80 \%$ from the P fertilizer (from 37.5 to $67.5 \mathrm{~kg} \mathrm{P} \mathrm{ha}^{-1}$ ) inversely reduced $\mathrm{PFP}_{\mathrm{P}}$ by $38.6 \%$ (from an average of 231.6 to $142.5 \mathrm{~kg} \mathrm{~kg}^{-1}$ ).

Table 4. Effects of N, P and biochar on plant $\mathrm{N}$ concentration, uptake, internal $\mathrm{N}$ use efficiency and partial $\mathrm{N}$ factor productivity at maturity.

\begin{tabular}{cccccccc}
\hline \multirow{2}{*}{ Treatment } & \multicolumn{2}{c}{ Concentration (\%) } & \multicolumn{2}{c}{ Uptake (kg ha $\left.{ }^{-1}\right)$} & $\begin{array}{c}\text { Internal Use } \\
\text { Efficiency }\end{array}$ & $\begin{array}{c}\text { Partial Factor } \\
\text { Productivity }\end{array}$ \\
\cline { 2 - 7 } & Grain & Straw & Grain & Straw & Total & $\left.\mathbf{( k g ~ k g ~}^{-1}\right)$ & $\mathbf{( k g ~ k g ~}^{-1} \mathbf{)}$ \\
\hline $\mathrm{N}_{1} \mathrm{P}_{1} \mathrm{~B}_{0}$ & $1.00 \mathrm{a}$ & $0.54 \mathrm{a}$ & $89.6 \mathrm{ab}$ & $43.3 \mathrm{a}$ & $132.9 \mathrm{ab}$ & $67.6 \mathrm{a}$ & $73.3 \mathrm{ab}$ \\
$\mathrm{N}_{1} \mathrm{P}_{1} \mathrm{~B}_{1}$ & $1.03 \mathrm{a}$ & $0.56 \mathrm{a}$ & $86.7 \mathrm{ab}$ & $44.2 \mathrm{a}$ & $130.8 \mathrm{ab}$ & $65.8 \mathrm{a}$ & $69.9 \mathrm{ab}$ \\
$\mathrm{N}_{1} \mathrm{P}_{2} \mathrm{~B}_{0}$ & $0.98 \mathrm{a}$ & $0.50 \mathrm{a}$ & $86.3 \mathrm{ab}$ & $39.0 \mathrm{a}$ & $125.2 \mathrm{ab}$ & $69.7 \mathrm{a}$ & $72.9 \mathrm{ab}$ \\
$\mathrm{N}_{1} \mathrm{P}_{2} \mathrm{~B}_{1}$ & $1.01 \mathrm{a}$ & $0.50 \mathrm{a}$ & $97.3 \mathrm{ab}$ & $40.7 \mathrm{a}$ & $138.1 \mathrm{ab}$ & $69.7 \mathrm{a}$ & $80.1 \mathrm{a}$ \\
$\mathrm{N}_{2} \mathrm{P}_{1} \mathrm{~B}_{0}$ & $1.02 \mathrm{a}$ & $0.60 \mathrm{a}$ & $91.4 \mathrm{ab}$ & $42.9 \mathrm{a}$ & $134.3 \mathrm{ab}$ & $66.6 \mathrm{a}$ & $50.1 \mathrm{c}$ \\
$\mathrm{N}_{2} \mathrm{P}_{1} \mathrm{~B}_{1}$ & $0.91 \mathrm{a}$ & $0.51 \mathrm{a}$ & $77.7 \mathrm{~b}$ & $38.4 \mathrm{a}$ & $116.1 \mathrm{~b}$ & $74.1 \mathrm{a}$ & $47.4 \mathrm{c}$ \\
$\mathrm{N}_{2} \mathrm{P}_{2} \mathrm{~B}_{0}$ & $0.99 \mathrm{a}$ & $0.61 \mathrm{a}$ & $87.4 \mathrm{ab}$ & $45.4 \mathrm{a}$ & $132.9 \mathrm{ab}$ & $66.5 \mathrm{a}$ & $49.0 \mathrm{c}$ \\
$\mathrm{N}_{2} \mathrm{P}_{2} \mathrm{~B}_{1}$ & $0.98 \mathrm{a}$ & $0.59 \mathrm{a}$ & $110.0 \mathrm{a}$ & $56.8 \mathrm{a}$ & $166.8 \mathrm{a}$ & $66.9 \mathrm{a}$ & $62.6 \mathrm{bc}$ \\
\hline \multicolumn{7}{c}{ Notes: Different lowercase letters within one column indicate significant differences $(p<5 \%)}$.
\end{tabular}

Table 5. Effects of N, P and biochar on plant P concentration, uptake, internal $\mathrm{P}$ use efficiency and partial $\mathrm{P}$ factor productivity at maturity.

\begin{tabular}{cccccccc}
\hline \multirow{2}{*}{ Treatment } & \multicolumn{2}{c}{ Concentration (\%) } & \multicolumn{2}{c}{ Uptake (kg ha ${ }^{-\mathbf{1}}$ ) } & $\begin{array}{c}\text { Internal Use } \\
\text { Efficiency }\end{array}$ & $\begin{array}{c}\text { Partial Factor } \\
\text { Productivity }\end{array}$ \\
\cline { 2 - 8 } & Grain & Straw & Grain & Straw & Total & $\left.\mathbf{( k g ~ k g}^{-\mathbf{1}}\right)$ & $\mathbf{( k g ~ k g}^{-\mathbf{1}} \mathbf{)}$ \\
\hline $\mathrm{N}_{1} \mathrm{P}_{1} \mathrm{~B}_{0}$ & $0.288 \mathrm{a}$ & $0.105 \mathrm{abc}$ & $25.2 \mathrm{a}$ & $8.3 \mathrm{~b}$ & $33.6 \mathrm{ab}$ & $261.6 \mathrm{~b}$ & $234.5 \mathrm{a}$ \\
$\mathrm{N}_{1} \mathrm{P}_{1} \mathrm{~B}_{1}$ & $0.263 \mathrm{ab}$ & $0.098 \mathrm{abc}$ & $22.2 \mathrm{a}$ & $7.5 \mathrm{~b}$ & $29.7 \mathrm{~b}$ & $284.4 \mathrm{ab}$ & $223.7 \mathrm{a}$ \\
$\mathrm{N}_{1} \mathrm{P}_{2} \mathrm{~B}_{0}$ & $0.271 \mathrm{ab}$ & $0.108 \mathrm{ab}$ & $23.8 \mathrm{a}$ & $8.3 \mathrm{~b}$ & $32.1 \mathrm{ab}$ & $270.2 \mathrm{ab}$ & $129.6 \mathrm{~b}$ \\
$\mathrm{~N}_{1} \mathrm{P}_{2} \mathrm{~B}_{1}$ & $0.271 \mathrm{ab}$ & $0.094 \mathrm{bc}$ & $26.1 \mathrm{a}$ & $7.7 \mathrm{~b}$ & $33.8 \mathrm{ab}$ & $284.5 \mathrm{ab}$ & $142.4 \mathrm{~b}$ \\
$\mathrm{~N}_{2} \mathrm{P}_{1} \mathrm{~B}_{0}$ & $0.266 \mathrm{ab}$ & $0.093 \mathrm{c}$ & $24.0 \mathrm{a}$ & $6.7 \mathrm{~b}$ & $30.7 \mathrm{~b}$ & $292.8 \mathrm{a}$ & $240.6 \mathrm{a}$ \\
$\mathrm{N}_{2} \mathrm{P}_{1} \mathrm{~B}_{1}$ & $0.268 \mathrm{ab}$ & $0.096 \mathrm{bc}$ & $23.2 \mathrm{a}$ & $7.0 \mathrm{~b}$ & $30.2 \mathrm{~b}$ & $286.3 \mathrm{ab}$ & $227.7 \mathrm{a}$ \\
$\mathrm{N}_{2} \mathrm{P}_{2} \mathrm{~B}_{0}$ & $0.257 \mathrm{~b}$ & $0.101 \mathrm{abc}$ & $22.8 \mathrm{a}$ & $7.6 \mathrm{~b}$ & $30.4 \mathrm{~b}$ & $291.0 \mathrm{ab}$ & $130.8 \mathrm{~b}$ \\
$\mathrm{~N}_{2} \mathrm{P}_{2} \mathrm{~B}_{1}$ & $0.256 \mathrm{~b}$ & $0.113 \mathrm{a}$ & $29.1 \mathrm{a}$ & $11.0 \mathrm{a}$ & $40.1 \mathrm{a}$ & $281.7 \mathrm{ab}$ & $167.0 \mathrm{~b}$ \\
\hline
\end{tabular}

The use of $\mathrm{P}$ fertilizer significantly $(p<5 \%$ ) increased grain $\mathrm{K}$ concentration (GKC) by $5.3 \%$ (Table 8). Less $P$ fertilizer application significantly lowered the GKC to $0.184 \%$ compared to $\mathrm{N}_{2} \mathrm{P}_{2} \mathrm{~B}_{1}$, which resulted in the greatest GKC of $0.202 \%$ (Table 6). By contrast, straw K concentration (SKC) was significantly $(p<5 \%)$ increased by $7.7 \%$ in response to biochar application (Table 8$)$. The addition of biochar to fertilizer uniformly generated a higher SKC, although no statistical significance was observed. A comparatively low SKC was achieved with the combined application of $67.5 \mathrm{~kg} \mathrm{P} \mathrm{ha}-1$ and $\mathrm{N}$ fertilizer, irrespective of the $\mathrm{N}$ fertilization level. Generally, biochar or fertilizer did not have a significant impact on $\mathrm{K}$ uptake into grain and straw. With the same application rate of $\mathrm{N}$ and biochar, an increase in $\mathrm{P}$ fertilizer led to more grain $\mathrm{K}$ uptake, especially for $\mathrm{N}_{2} \mathrm{P}_{2} \mathrm{~B}_{1}$, in which $\mathrm{SKC}$ was increased by over $44 \%$ compared with that in $\mathrm{N}_{2} \mathrm{P}_{1} \mathrm{~B}_{1}$. K uptake by straw improved more or less by blending biochar with the corresponding $\mathrm{N}$ and $\mathrm{P}$ fertilizer, except $\mathrm{N}_{1} \mathrm{P}_{1} \mathrm{~B}_{0}$. The lowest $\mathrm{K}$ uptake by straw $\left(110.6 \mathrm{~kg} \mathrm{~K} \mathrm{ha}^{-1}\right)$ was obtained from $\mathrm{N}_{2} \mathrm{P}_{2} \mathrm{~B}_{0}$, while the mean values significantly increased to $161.6 \mathrm{~kg} \mathrm{~K} \mathrm{ha}^{-1}$, the highest $\mathrm{K}$ uptake by straw, with incorporation of the fertilizer with biochar. A consistent trend was also detected for the total $\mathrm{K}$ uptake by rice between different treatments. Internal $\mathrm{K}$ use efficiency ( $\left.\mathrm{IE}_{\mathrm{K}}\right)$ was significantly $(p<5 \%)$ decreased by $6.6 \%$ in response to biochar application (Table 8). There was a negative effect of biochar on $\mathrm{IE}_{\mathrm{K}}$, which had values between 59.9 and 
$69.5 \mathrm{~kg} \mathrm{~kg}^{-1}$. Biochar significantly increased the K partial factor productivity only when the highest amounts of $\mathrm{N}$ and $\mathrm{P}$ fertilizer were mixed.

Table 6. Effects of N, P and biochar on plant K concentration, uptake, internal K use efficiency and partial $\mathrm{K}$ factor productivity at maturity.

\begin{tabular}{cccccccc}
\hline \multirow{2}{*}{ Treatment } & \multicolumn{2}{c}{ Concentration (\%) } & \multicolumn{2}{c}{ Uptake (kg ha ${ }^{-1}$ ) } & $\begin{array}{c}\text { Internal Use } \\
\text { Efficiency }\end{array}$ & $\begin{array}{c}\text { Partial Factor } \\
\text { Productivity }\end{array}$ \\
\cline { 2 - 7 } & Grain & Straw & Grain & Straw & Total & $\left.\mathbf{( k g ~ k g}^{-1}\right)$ & $\left.\mathbf{( k g ~ k g}^{-1}\right)$ \\
\hline $\mathrm{N}_{1} \mathrm{P}_{1} \mathrm{~B}_{0}$ & $0.184 \mathrm{~b}$ & $1.33 \mathrm{ab}$ & $16.16 \mathrm{~b}$ & $117.8 \mathrm{ab}$ & $134.0 \mathrm{ab}$ & $65.9 \mathrm{ab}$ & $130.3 \mathrm{~b}$ \\
$\mathrm{~N}_{1} \mathrm{P}_{1} \mathrm{~B}_{1}$ & $0.188 \mathrm{ab}$ & $1.34 \mathrm{ab}$ & $15.75 \mathrm{~b}$ & $113.8 \mathrm{~b}$ & $129.6 \mathrm{~b}$ & $66.1 \mathrm{ab}$ & $124.3 \mathrm{~b}$ \\
$\mathrm{~N}_{1} \mathrm{P}_{2} \mathrm{~B}_{0}$ & $0.193 \mathrm{ab}$ & $1.28 \mathrm{~b}$ & $17.04 \mathrm{ab}$ & $112.3 \mathrm{~b}$ & $129.3 \mathrm{~b}$ & $68.4 \mathrm{a}$ & $129.6 \mathrm{~b}$ \\
$\mathrm{~N}_{1} \mathrm{P}_{2} \mathrm{~B}_{1}$ & $0.200 \mathrm{ab}$ & $1.39 \mathrm{ab}$ & $19.34 \mathrm{ab}$ & $136.0 \mathrm{ab}$ & $155.3 \mathrm{ab}$ & $63.1 \mathrm{ab}$ & $142.4 \mathrm{ab}$ \\
$\mathrm{N}_{2} \mathrm{P}_{1} \mathrm{~B}_{0}$ & $0.190 \mathrm{ab}$ & $1.34 \mathrm{ab}$ & $17.06 \mathrm{ab}$ & $121.7 \mathrm{ab}$ & $138.8 \mathrm{ab}$ & $65.4 \mathrm{ab}$ & $133.7 \mathrm{ab}$ \\
$\mathrm{N}_{2} \mathrm{P}_{1} \mathrm{~B}_{1}$ & $0.184 \mathrm{~b}$ & $1.49 \mathrm{a}$ & $15.84 \mathrm{~b}$ & $126.4 \mathrm{ab}$ & $142.3 \mathrm{ab}$ & $59.9 \mathrm{~b}$ & $126.4 \mathrm{~b}$ \\
$\mathrm{~N}_{2} \mathrm{P}_{2} \mathrm{~B}_{0}$ & $0.193 \mathrm{ab}$ & $1.25 \mathrm{~b}$ & $17.11 \mathrm{ab}$ & $110.6 \mathrm{~b}$ & $127.7 \mathrm{~b}$ & $69.5 \mathrm{a}$ & $130.8 \mathrm{~b}$ \\
$\mathrm{~N}_{2} \mathrm{P}_{2} \mathrm{~B}_{1}$ & $0.202 \mathrm{a}$ & $1.41 \mathrm{ab}$ & $22.94 \mathrm{a}$ & $161.6 \mathrm{a}$ & $184.5 \mathrm{a}$ & $62.2 \mathrm{ab}$ & $167.0 \mathrm{a}$ \\
\hline
\end{tabular}

Notes: Different lowercase letters within one column indicate significant differences $(p<5 \%)$.

\subsection{Soil Properties}

For soil properties under different treatments, see Table 7. P fertilizer significantly $(p<5 \%)$ influenced CEC, which was markedly increased by $14.7 \%$ in $\mathrm{N}_{1} \mathrm{P}_{2} \mathrm{~B}_{1}$ compared with $\mathrm{N}_{1} \mathrm{P}_{1} \mathrm{~B}_{1}$ (Table 8). Likewise, the application of $\mathrm{P}$ fertilizer exerted a positive but more dramatic $(p<1 \%)$ effect on exchangeable $\mathrm{Ca}(\mathrm{ECa})$, which was increased by $4.1 \%$ with $\mathrm{P}$ fertilizer (Table 8 ). Meanwhile, ECa was decreased significantly $(p<1 \%)$ by $4.0 \%$ in response to biochar application (Table 8$)$. As a result, the application of $\mathrm{N}_{1} \mathrm{P}_{2} \mathrm{~B}_{0}$ and $\mathrm{N}_{2} \mathrm{P}_{2} \mathrm{~B}_{0}$ revealed significantly higher ECa than $\mathrm{N}_{2} \mathrm{P}_{1} \mathrm{~B}_{1}$ and $\mathrm{N}_{1} \mathrm{P}_{1} \mathrm{~B}_{1}$. The exchangeable $\mathrm{Mg}(\mathrm{EMg})$ significantly resulted in a $5.2 \%$ increase $(p<5 \%)$ in response to the addition of $\mathrm{P}$ fertilizer, but a $9.0 \%$ decline $(p<1 \%)$ in response to biochar application (Table 8$)$. The effect of the P fertilizer by biochar interaction was also significant $(p<5 \%)$ for EMg (Table 8$)$. The content of $\mathrm{EMg}$ was higher for the $\mathrm{P}$ fertilizer than either biochar amendment or their combined application. Therefore, relatively higher mean values of EMg were achieved with pure fertilizer treatment, such as $\mathrm{N}_{1} \mathrm{P}_{2} \mathrm{~B}_{0}$ and $\mathrm{N}_{2} \mathrm{P}_{2} \mathrm{~B}_{0}$. The soil exchangeable $\mathrm{Na}$ and exchangeable $\mathrm{K}$ did not show any significant response to either biochar amendment or fertilization. The EBC, composed of $\mathrm{ECa}, \mathrm{EMg}$, exchangeable $\mathrm{Na}$ and $\mathrm{K}$, was markedly increased by $4.1 \%(p<5 \%)$ in response to $\mathrm{P}$ fertilizer, but decreased by $5.2 \%(p<1 \%)$ in response to biochar amendment (Table 8). The treatments had no significant effect on both exchangeable $\mathrm{H}$ and base saturation (BS). Overall, biochar significantly $(p<5 \%)$ resulted in a $17.3 \%$ decrease in the EAl, accounting for $73.2 \%$ to $82.3 \%$ of the exchangeable acidity (Table 8 ). However, this decrease was not enough to cause a statistically significant reduction in the exchangeable acidity. The contents of exchangeable acidity and EAl were significantly higher in $\mathrm{N}_{1} \mathrm{P}_{1} \mathrm{~B}_{0}$ than $\mathrm{N}_{1} \mathrm{P}_{1} \mathrm{~B}_{1}$, while this was vice versa for $\mathrm{pH}$. The biochar application significantly $(p<5 \%)$ increased soil $\mathrm{pH}$ by $1.7 \%$ (Table 8). Despite the considerable electrical conductivity, biochar did not cause any significant increase in the electrical conductivity of soil. $\mathrm{N}_{1} \mathrm{P}_{1} \mathrm{~B}_{1}$-treated soil recorded the lowest organic matter, $\mathrm{TN}$, available $\mathrm{N}, \mathrm{AP}$ and $\mathrm{AK}$ with respective mean values of $38.7 \mathrm{~g} \mathrm{~kg}^{-1}, 1.79 \mathrm{~g} \mathrm{~kg}^{-1}, 154.9 \mathrm{mg} \mathrm{kg}^{-1}$, $4.5 \mathrm{mg} \mathrm{kg}^{-1}$ and $51.7 \mathrm{mg} \mathrm{kg}^{-1}$. Moreover, the values of those parameters in $\mathrm{N}_{1} \mathrm{P}_{2} \mathrm{~B}_{1}$ were significantly enhanced compared to $\mathrm{N}_{1} \mathrm{P}_{1} \mathrm{~B}_{1}$. TN was significantly changed by the $\mathrm{N}$ fertilizer and $\mathrm{P}$ fertilizer by biochar interactions (Table 8). AP notably increased by $19.9 \%(p<1 \%)$ and AK by $17.5 \%(p<5 \%)$ in response to the $\mathrm{P}$ fertilizer (Table 8). 
Table 7. Soil properties in response to N, P and biochar applied in various proportions.

\begin{tabular}{|c|c|c|c|c|c|c|c|c|}
\hline Parameter & $\mathbf{N}_{1} \mathbf{P}_{1} \mathbf{B}_{0}$ & $\mathbf{N}_{1} \mathbf{P}_{1} \mathbf{B}_{1}$ & $\mathbf{N}_{1} \mathbf{P}_{2} \mathbf{B}_{0}$ & $\mathbf{N}_{1} \mathbf{P}_{2} \mathbf{B}_{1}$ & $\mathbf{N}_{2} \mathbf{P}_{1} \mathbf{B}_{0}$ & $\mathbf{N}_{2} \mathbf{P}_{1} \mathbf{B}_{1}$ & $\mathbf{N}_{2} \mathbf{P}_{2} \mathbf{B}_{0}$ & $\mathbf{N}_{2} \mathbf{P}_{2} \mathbf{B}_{1}$ \\
\hline $\mathrm{CEC}\left(\mathrm{cmol} \mathrm{kg}^{-1}\right)$ & $8.37 \mathrm{ab}$ & $8.17 b$ & $8.97 \mathrm{ab}$ & $9.37 \mathrm{a}$ & $8.43 \mathrm{ab}$ & $8.10 \mathrm{~b}$ & $8.73 \mathrm{ab}$ & $8.37 \mathrm{ab}$ \\
\hline $\mathrm{ECa}\left(\mathrm{cmol} \mathrm{kg}^{-1}\right)$ & $4.45 \mathrm{ab}$ & $4.20 \mathrm{c}$ & $4.65 \mathrm{a}$ & $4.46 \mathrm{ab}$ & $4.56 \mathrm{ab}$ & $4.35 \mathrm{bc}$ & $4.63 \mathrm{a}$ & $4.56 \mathrm{ab}$ \\
\hline $\operatorname{EMg}\left(\mathrm{cmol} \mathrm{kg}^{-1}\right)$ & $1.04 \mathrm{~b}$ & $0.95 \mathrm{c}$ & $1.13 \mathrm{a}$ & 0.99 bc & $1.03 \mathrm{bc}$ & $1.00 \mathrm{bc}$ & $1.13 \mathrm{a}$ & $0.99 \mathrm{bc}$ \\
\hline ENa $\left(\mathrm{cmol} \mathrm{kg}^{-1}\right)$ & $0.13 \mathrm{a}$ & $0.09 \mathrm{~b}$ & $0.11 \mathrm{ab}$ & $0.11 \mathrm{ab}$ & $0.13 \mathrm{a}$ & $0.11 \mathrm{ab}$ & $0.11 \mathrm{ab}$ & $0.11 \mathrm{ab}$ \\
\hline $\mathrm{EK}\left(\mathrm{cmol} \mathrm{kg}^{-1}\right)$ & $0.16 \mathrm{a}$ & $0.18 \mathrm{a}$ & $0.17 \mathrm{a}$ & $0.20 \mathrm{a}$ & $0.22 \mathrm{a}$ & $0.15 \mathrm{a}$ & $0.21 \mathrm{a}$ & $0.16 \mathrm{a}$ \\
\hline $\mathrm{EH}\left(\mathrm{cmol} \mathrm{kg}^{-1}\right)$ & $0.15 \mathrm{a}$ & $0.11 \mathrm{a}$ & $0.11 \mathrm{a}$ & $0.15 \mathrm{a}$ & $0.13 \mathrm{a}$ & $0.12 \mathrm{a}$ & $0.19 \mathrm{a}$ & $0.18 \mathrm{a}$ \\
\hline $\operatorname{EAl}\left(\mathrm{cmol} \mathrm{kg}^{-1}\right)$ & $0.58 \mathrm{a}$ & $0.33 \mathrm{~b}$ & $0.51 \mathrm{ab}$ & $0.45 \mathrm{ab}$ & $0.54 \mathrm{a}$ & $0.47 \mathrm{ab}$ & $0.52 \mathrm{a}$ & $0.53 \mathrm{a}$ \\
\hline $\mathrm{EA}\left(\mathrm{cmol} \mathrm{kg}^{-1}\right)$ & $0.73 \mathrm{a}$ & $0.45 \mathrm{~b}$ & $0.62 \mathrm{ab}$ & $0.60 \mathrm{ab}$ & $0.67 \mathrm{ab}$ & $0.59 \mathrm{ab}$ & $0.71 \mathrm{a}$ & $0.70 \mathrm{ab}$ \\
\hline $\mathrm{EBC}\left(\mathrm{cmol} \mathrm{kg}^{-1}\right)$ & $5.78 \mathrm{abc}$ & $5.43 \mathrm{c}$ & $6.07 \mathrm{a}$ & $5.76 \mathrm{abc}$ & $5.93 \mathrm{ab}$ & $5.61 \mathrm{bc}$ & $6.07 \mathrm{a}$ & $5.81 \mathrm{ab}$ \\
\hline BS (\%) & $70.1 \mathrm{a}$ & $66.6 \mathrm{a}$ & $67.7 \mathrm{a}$ & $61.5 \mathrm{a}$ & $70.4 \mathrm{a}$ & $69.2 \mathrm{a}$ & $69.6 \mathrm{a}$ & $69.7 \mathrm{a}$ \\
\hline $\mathrm{pH}$ & $5.01 \mathrm{~b}$ & $5.23 \mathrm{a}$ & $5.09 \mathrm{ab}$ & $5.11 \mathrm{ab}$ & $5.11 \mathrm{ab}$ & $5.10 \mathrm{ab}$ & $5.04 \mathrm{~b}$ & $5.16 \mathrm{ab}$ \\
\hline $\mathrm{EC}\left(\mu \mathrm{S} \mathrm{cm}^{-1}\right)$ & $133.4 \mathrm{a}$ & $120.7 \mathrm{ab}$ & $116.2 \mathrm{ab}$ & $120.8 \mathrm{ab}$ & $108.2 \mathrm{~b}$ & $118.1 \mathrm{ab}$ & $111.2 \mathrm{ab}$ & $121.4 \mathrm{ab}$ \\
\hline $\mathrm{OM}\left(\mathrm{g} \mathrm{kg}^{-1}\right)$ & $43.7 \mathrm{a}$ & $38.7 \mathrm{~b}$ & $43.1 \mathrm{ab}$ & $43.8 \mathrm{a}$ & $42.2 \mathrm{ab}$ & $43.4 \mathrm{ab}$ & $44.3 \mathrm{a}$ & $44.0 \mathrm{a}$ \\
\hline $\mathrm{TN}\left(\mathrm{g} \mathrm{kg}^{-1}\right)$ & $2.11 \mathrm{ab}$ & $1.79 \mathrm{c}$ & $1.86 \mathrm{bc}$ & $2.15 \mathrm{a}$ & $2.06 \mathrm{abc}$ & $2.06 \mathrm{abc}$ & $2.13 \mathrm{ab}$ & $2.05 \mathrm{abc}$ \\
\hline $\mathrm{AN}\left(\mathrm{mg} \mathrm{kg}^{-1}\right)$ & $168.9 \mathrm{a}$ & $154.9 \mathrm{~b}$ & $167.1 \mathrm{ab}$ & $172.2 \mathrm{a}$ & $170.1 \mathrm{a}$ & $173.8 \mathrm{a}$ & $167.3 \mathrm{ab}$ & $165.2 \mathrm{ab}$ \\
\hline $\mathrm{AP}\left(\mathrm{mg} \mathrm{kg}^{-1}\right)$ & $5.0 \mathrm{ab}$ & $4.5 \mathrm{~b}$ & $5.5 \mathrm{ab}$ & $6.5 \mathrm{a}$ & $5.2 \mathrm{ab}$ & $4.7 \mathrm{~b}$ & $5.6 \mathrm{ab}$ & $6.6 \mathrm{a}$ \\
\hline $\mathrm{AK}\left(\mathrm{mg} \mathrm{kg}^{-1}\right)$ & $71.5 \mathrm{abcd}$ & $51.7 \mathrm{~d}$ & $81.1 \mathrm{ab}$ & $87.8 \mathrm{a}$ & $58.8 \mathrm{~cd}$ & $65.8 \mathrm{bcd}$ & $58.8 \mathrm{~cd}$ & $72.6 \mathrm{abc}$ \\
\hline
\end{tabular}

Notes: CEC: Cation exchange capacity; ECa: Exchangeable Ca; EMg: Exchangeable Mg; ENa: Exchangeable Na; EK: Exchangeable K; EH: Exchangeable H; EAl: Exchangeable Al; EA: Exchangeable acidity; EBC: Exchangeable base cations; BS: Base saturation; EC: Electrical conductivity; OM: Organic matter; TN: Total N; AN: Available N; AP: Available P; AK: Available K; and different lowercase letters within one row indicate significant differences $(p<5 \%)$.

Table 8. ANOVA for the effects of N, P and Biochar (B) on plant- and soil-related parameters.

\begin{tabular}{|c|c|c|c|c|c|c|}
\hline \multirow{2}{*}{ Parameter } & \multicolumn{6}{|c|}{ Source } \\
\hline & $\mathbf{N}$ & $\mathbf{P}$ & B & $\mathbf{N} \times \mathbf{B}$ & $\mathbf{P} \times \mathbf{B}$ & $\mathbf{N} \times \mathbf{P} \times \mathbf{B}$ \\
\hline $\mathrm{PFP}_{\mathrm{N}}$ & $* *$ & & & & & \\
\hline SPC & & & & * & & \\
\hline SPU & & $*$ & & * & & \\
\hline $\mathrm{PFP}_{\mathrm{P}}$ & & $* *$ & & & & \\
\hline GKC & & $*$ & & & & \\
\hline SKC & & & * & & & \\
\hline $\mathrm{IE}_{\mathrm{K}}$ & & & * & & & \\
\hline CEC & & $*$ & & & & \\
\hline $\mathrm{ECa}$ & & $* *$ & $* *$ & & & \\
\hline $\mathrm{EMg}$ & & $*$ & ** & & * & \\
\hline EAl & & & * & & & \\
\hline EBC & & * & $* *$ & & & \\
\hline $\mathrm{pH}$ & & & * & & & \\
\hline $\mathrm{TN}$ & & & & & & * \\
\hline $\mathrm{AP}$ & & $* *$ & & & & \\
\hline $\mathrm{AK}$ & & $*$ & & & & \\
\hline
\end{tabular}

Notes: ANOVA: Analysis of variance; $\mathrm{PFP}_{\mathrm{N}}$ : N partial factor productivity; SPC: Straw P concentration; SPU: Straw P uptake; $\mathrm{PFP}_{\mathrm{P}}$ : P partial factor productivity; GKC: Grain K concentration; SKC: Straw K concentration; $\mathrm{IE}_{\mathrm{K}}$ : Internal K use efficiency; CEC: Cation exchange capacity; ECa: Exchangeable Ca; EMg: Exchangeable Mg; EAl: Exchangeable Al; EBC: Exchangeable base cations; TN: Total N; AP: Available P; AK: Available K; *: Significant at $p<5 \%$; and $* *$ : Significant at $p<1 \%$.

The content of mineral $\mathrm{N}$ (Nmin) at different growth stages is illustrated in Figure 3. Soils under the different treatments had comparatively higher $\mathrm{NH}_{4}{ }^{+}-\mathrm{N}$ content than $\mathrm{NO}_{3}{ }^{-}-\mathrm{N}$ during tillering, booting and heading stages. The highest $\mathrm{NO}_{3}{ }^{-}-\mathrm{N}$ content in soil was recorded during the heading stage, followed by the booting stage, maturity stage and tillering stage. As for $\mathrm{NH}_{4}{ }^{+}-\mathrm{N}$, there was a general trend, with the content dropping during harvesting. Generally, the predominant Nmin in pre-harvest soil was $\mathrm{NH}_{4}{ }^{+}-\mathrm{N}$, although the ratio between $\mathrm{NH}_{4}{ }^{+}-\mathrm{N}$ and $\mathrm{NO}_{3}{ }^{-}-\mathrm{N}$ leveled out to be around 1.0 after harvest. $\mathrm{NH}_{4}{ }^{+}-\mathrm{N}$ content was marginally reduced by biochar in the samples taken during the tillering and heading stages, although this was not the case at the end of the 
trial period. $\mathrm{P}$ fertilizer-treated soil contained modestly higher $\mathrm{NH}_{4}{ }^{+}-\mathrm{N}$ and $\mathrm{NO}_{3}{ }^{-}-\mathrm{N}$ during the heading stage. In particular, $\mathrm{NH}_{4}{ }^{+}-\mathrm{N}$ and $\mathrm{NO}_{3}{ }^{-}-\mathrm{N}$ content in soil significantly increased by $21.5 \%$ and $15.7 \%$, respectively, under $\mathrm{N}_{2} \mathrm{P}_{2} \mathrm{~B}_{0}$ treatment compared to $\mathrm{N}_{2} \mathrm{P}_{1} \mathrm{~B}_{0}$. $\mathrm{NO}_{3}{ }^{-}-\mathrm{N}$ content was more or less homogeneous in different growing periods.
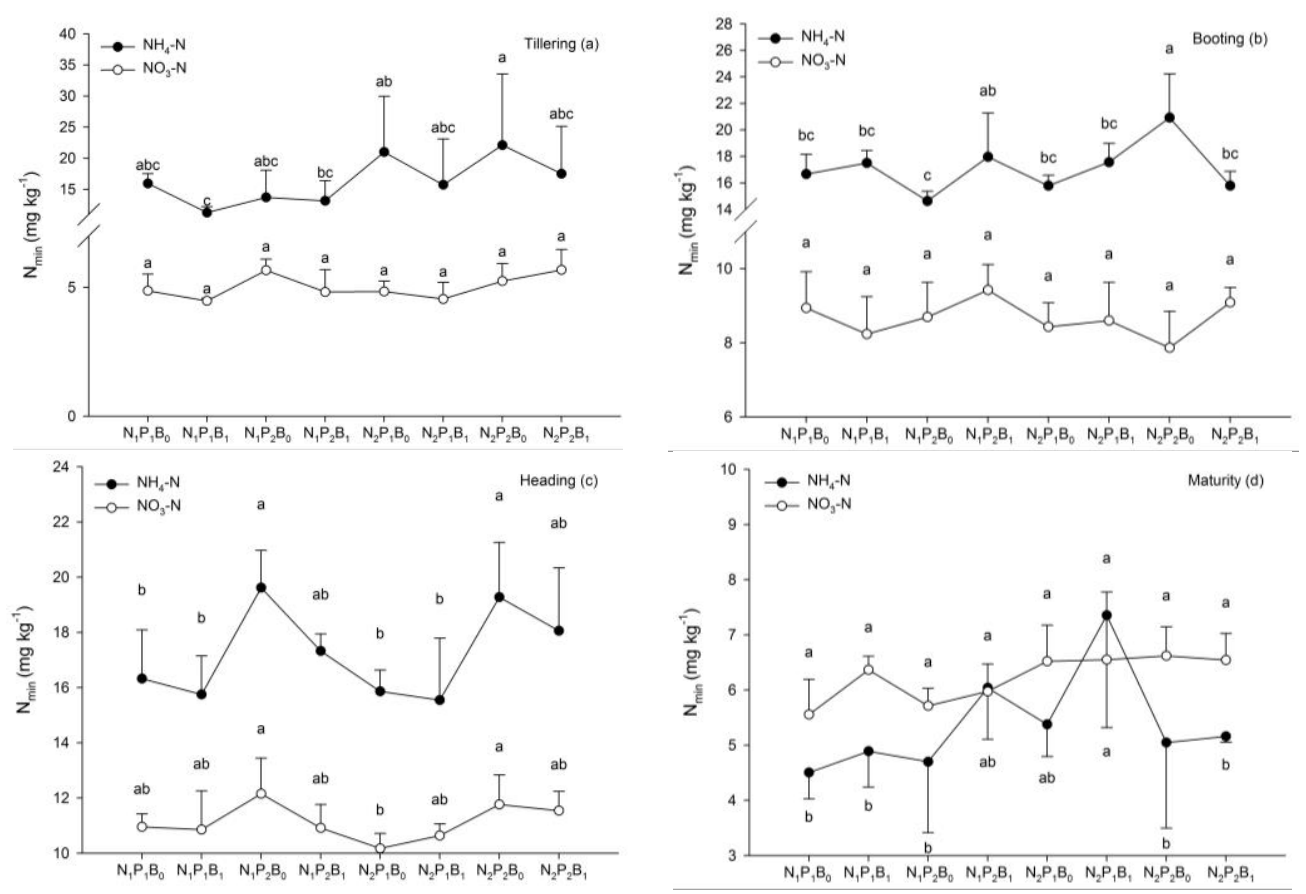

Figure 3. Effects of $\mathrm{N}$ and $\mathrm{P}$ application and biochar amendment on soil ammonium $\mathrm{N}$ and nitrate $\mathrm{N}$ at the (a) tillering stage, (b) booting stage, (c) heading stage and (d) maturity stage. Different lowercase letters above or below bars indicate significant differences $(p<5 \%)$.

\section{Discussion}

\subsection{Soil Properties}

In general, the addition of biochar can elevate soil $\mathrm{pH}$ due to its liming effect on soil. Peng et al. found an increase of $0.1-0.46(p<1 \%)$ in the $\mathrm{pH}$ of an Ultisol after the addition of biochar derived from rice straw [41]. In the current study, soil $\mathrm{pH}$ was significantly increased by approximately 0.1 unit on average when the rice straw-derived biochar was applied. Furthermore, Lu et al. also observed the liming effect in a subtropical paddy soil, which was accentuated at the higher dose of biochar with smaller particle size [42]. Unlike soil $\mathrm{pH}$, soil exchangeable acidity reflects the exchange capacity of potential soil acid consisting of exchangeable $\mathrm{H}$ and EAl. There was a negative relationship between the soil exchangeable acidity and the application rate and alkalinity of biochar in the acidic soil [43,44]. In this study, the addition of biochar significantly decreased soil EAl, with no significant changes in soil exchangeable acidity from all treatments.

Biochar application did not exert a significant effect on soil CEC. He et al. concluded that the effect of biochar addition on soil CEC depended on soil, biochar and duration of biochar in the soil [45]. The application of biochar increased soil CEC as a consequence of the increase in charge density per unit surface of biochar from strengthening oxidation and/or expanding surface area for cation adsorption [46]. Novak et al. have indicated that biochar did not change CEC in a Norfolk soil even after a 67-day incubation period, implying that biochar produced at higher temperature $\left(700{ }^{\circ} \mathrm{C}\right)$ was so recalcitrant that it resisted the oxidation of biochar surface and microbial degradation [47]. The temperate stability of rice straw biochar may result in a negligible improvement in soil CEC over a short timeframe. On the other hand, P fertilizer caused a significant increase (by 6.7\%) in soil CEC. 
A large number of base cations, such as $\mathrm{Ca}^{2+}$ and $\mathrm{Mg}^{2+}$ in the $\mathrm{P}$ fertilizer contributed to this increase in soil CEC, which is consistent with a previous study on acidic soils [48].

Therefore, the release of base cations in P fertilizer was beneficial to soil ECa, EMg and EBC. We found that ECa and EMg significantly decreased with the addition of biochar at $2.25 \mathrm{tha}^{-1}$, although this same rate had no significant effect on exchangeable $\mathrm{Na}$ and $\mathrm{K}$. The discrepant results could be linked to the capacity of biochar to adsorb cations with different valence values. Accordingly, the soil EBC, consisting primarily of ECa and EMg, decreased after applying biochar. Based on the partial Eta squared values (not shown), the effects of biochar, $\mathrm{P}$ fertilizer and their interaction on EMg in decreasing order were $\mathrm{B}(0.655)>\mathrm{P}(0.378)>\mathrm{B} \times \mathrm{P}(0.254)$, which suggested that the negative effect of biochar outperformed the positive effect of $P$ fertilizer.

There have been several reports of the impact of biochar on soil nutrient content. For instance, Ming et al. found that biochar induced different changes in the TN, AP and AK of subtropical paddy soil, depending on biochar type and quantity [49]. A two-year consecutive field study conducted in a subtropical paddy proved that only biochar applied at $40 \mathrm{t} \mathrm{ha}^{-1}$ could significantly increase $\mathrm{TN}$ in soil [50]. However, the complex interactive effect of biochar and fertilizer on soil TN examined in this study was frequently ignored, particularly when they were mixed together. Lin et al. confirmed that increasing the input of $P$ fertilizer was an effective approach to elevating soil $P$ availability in cold waterlogged paddy fields [51]. The increase in soil AP and AK may be related directly to the significant impact of $\mathrm{P}$ fertilizer on soil CEC, a key soil fertility indicator.

\subsection{Nutrient Uptake}

Partial factor productivity is a parameter measuring the contribution of nutrients from both the native soil and exotic inputs to the economic output [52]. In the present study, $\operatorname{PFP}_{\mathrm{N}}$ and $\mathrm{PFP}_{\mathrm{P}}$ decreased significantly with increased levels of $\mathrm{N}$ supply from 120.0 to $180.0 \mathrm{~kg} \mathrm{ha}^{-1}$ and increased levels of P supply from 37.5 to $67.5 \mathrm{~kg} \mathrm{ha}^{-1}$, respectively. Likewise, a highly significant decrease in $\mathrm{PFP}_{\mathrm{N}}$ was detected as the amount of applied $\mathrm{N}$ increased under the maize cropping system, which was shown to be independent of site or year [53]. Comparatively similar logarithmic equations (all $R^{2}>0.99$ ) illustrated the inverse relationship between $P$ application rate and PFP $_{P}$ under subtropical field conditions [54]. In our study, the available nutrients absorbed by rice in a cold waterlogged paddy field were mainly obtained from the fertilizer, other than the soil itself. Therefore, the decrease in $\mathrm{PFP}_{\mathrm{N}}$ and $\mathrm{PFP}_{\mathrm{P}}$ was presumably due to the increased $\mathrm{N}$ and $\mathrm{P}$ supply, which did not cause corresponding increases in rice yield.

The internal nutrient use efficiency represents a plant's ability to transform nutrient uptake into grain production. The $\mathrm{IE}_{\mathrm{K}}$ in this study is comparable with the result of Islam and Muttaleb, who obtained $\mathrm{IE}_{\mathrm{K}}$ values of $41.82-86.36 \mathrm{~kg} \mathrm{~kg}^{-1}$ with various $\mathrm{K}$ application rates during various years in a wetland rice ecosystem under a subtropical climate [55]. It has been reported that $\mathrm{IE}_{\mathrm{K}}$ was associated with $\mathrm{K}$ absorption, translocation and distribution in plant tissues at the cellular level [56]. In the present study, we found that a higher $\mathrm{K}$ uptake into rice was not accompanied by an increased rice yield when biochar was applied. This indicated the potential benefit of biochar in terms of $\mathrm{K}$ uptake by roots.

The uptake of nutrients by plants can be directly affected by biochar and/or fertilizer-induced changes in soil nutrient states. A meta-analysis of 371 independent experiments revealed the superiority of biochar in increasing plant $\mathrm{P}$ and $\mathrm{K}$ contents over fertilizer according to the improvement in their availabilities through reduction in leaching losses and soil liming [57]. However, our analysis found that GKC and SKC responded positively to $P$ fertilizer and biochar, respectively. As a rule, the majority of $\mathrm{K}$ uptake by rice is allocated to straw before the heading stage. Therefore, responses to applied $\mathrm{P}$ fertilizer and biochar for $\mathrm{K}$ concentration in rice were highly dependent on the growing stage in our study. Liu et al. also demonstrated that rice straw biochar significantly increased SKC by $13.7 \%$ and $12.0 \%$, respectively, relative to the $\mathrm{CK}$ in a cold waterlogged paddy field for two consecutive rice growing cycles [58]. Based on the partial Eta squared values (not shown), the effect of $\mathrm{N}$ fertilizer by 
biochar interaction (0.260) was comparable with that of $P$ fertilizer $(0.256)$, which suggested that the combined application of $\mathrm{N}$ fertilizer and biochar was as effective as application of $\mathrm{P}$ fertilizer alone in increasing SPU. Nevertheless, SPC was significantly suppressed due to negative interactions between $\mathrm{N}$ fertilizer and biochar. This may be due to the dilution effect dictated by the greater dry matter production of rice straw.

\subsection{Crop Production}

As confirmed by previous research using meta-analysis, the application of biochar in soil can result in increased crop growth, thus significantly enhancing crop production in terms of either yield or biomass [59]. On the contrary, several studies have also reported negative responses of plant performance to biochar, which has been attributed to the elevated $\mathrm{pH}$ [60]. The various effects of biochar application on a crop system were mainly ascribed to the characteristics of biochar used, soil type, crop species, climate condition, and so on. Solaiman et al. reported that oil mallee biochar boosted wheat yield, while biochar produced by paper mill waste had destructive effects $[61,62]$. Chen et al. found no difference of wheat yield with the addition of biochar on alluvial soil in a pot experiment, although biochar significantly increased wheat yield on loess soil [63]. The addition of biochar benefited crop yield in acidic soil, although it was not always effective in calcareous soil $[64,65]$. According to Graber et al., wood-derived biochar has been demonstrated to significantly enhance pepper plant development, including yield, although it had no effect on tomato yield despite enhancing plant height and leaf size [66]. Results from a field trail across multiple years and in multiple locations across the USA supported the hypothesis that crop yield in different locations responds differently to complicated interactions of soil, biochar and climate [67].

This study suggested that fertilizer application at different rates and biochar amendment have no significant effect on rice yield. Soil in cold waterlogged paddy fields was characterized by low temperature and poor aeration conditions, which often caused a decrease in root activity and influenced nutrient uptake by plants. Therefore, more fertilizer, especially $\mathrm{N}$ fertilizer, may not essentially ameliorate the bad situation of roots and increase plant yield.

Moreover, the addition of biochar to chemical fertilizer resulted in no significant change in the rice yield, except for $\mathrm{N}_{2} \mathrm{P}_{2} \mathrm{~B}_{0}$ and $\mathrm{N}_{2} \mathrm{P}_{2} \mathrm{~B}_{1}$ treatment. There is an argument that the high $\mathrm{C} / \mathrm{N}$ ratio of biochar might even restrict soil $\mathrm{N}$ availability, which probably induces a reduction in crop production [68]. In the present study, the $\mathrm{C} / \mathrm{N}$ ratio of straw-derived biochar was as high as about 70 . Compared to $\mathrm{N}_{2} \mathrm{P}_{2} \mathrm{~B}_{0}$ treatment, the $\mathrm{C} / \mathrm{N}$ ratio of $\mathrm{N}_{2} \mathrm{P}_{2} \mathrm{~B}_{1}$ treatment may be more appropriate in enabling rice to obtain higher yields, which are mainly attributed to significant improvements in grains per panicle. This was consistent with the findings of Chen et al., who found that biochar increased grains per panicle through promoting rice grain filling under temperate climate conditions [69].

In the current study, there is scarce information about the yield effects resulting from biochar application. The potential improvement in crop yield from the addition of biochar has been explained by several mechanisms, such as improved soil properties, favorable surroundings of root growth and modified soil nutrient status [70]. Given the short duration of this trial, the effect of biochar on crop yield may be masked temporarily, which was confirmed under a maize-soybean rotation [71]. However, soil properties were partly changed by straw-derived biochar amendment, as discussed above. Hence, the response of yield to biochar warrants further investigation.

\section{Conclusions}

The results suggested a positive response of $\mathrm{pH}$ and SKC to the soil applied with biochar for cold waterlogged paddy fields. However, biochar application was shown to significantly reduce $\mathrm{IE}_{\mathrm{K}}, \mathrm{ECa}$, $\mathrm{EMg}, \mathrm{EAl}$ and EBC in cold waterlogged paddy fields. Significant increases in SPU, GKC, CEC, ECa, $\mathrm{EMg}, \mathrm{EBC}, \mathrm{AP}$ and $\mathrm{AK}$ were observed when $\mathrm{P}$ fertilizer was added. $\mathrm{PFP}_{\mathrm{N}}$ and $\mathrm{PFP}_{\mathrm{P}}$ were significantly lowered by increasing the application rate of $\mathrm{N}$ and $\mathrm{P}$ fertilizer, respectively. In addition, interactions of biochar and fertilizer had an impact on crop performance and soil properties for cold waterlogged 
paddy fields. For instance, $\mathrm{N}$ fertilizer with biochar interactions notably promoted SPU, but had a negative effect on SPC. The effect of interactions between P fertilizer and biochar was a marked decrease in soil EMg. The statistical data indicated the complex interaction of biochar, P fertilizer and $\mathrm{N}$ fertilizer with $\mathrm{TN}$ in soil. Compared to pure fertilizers in the farmers' fertilization practice, biochar-fertilizer combinations gave a better performance in terms of rice yield. However, rice yield and biomass production were not significantly affected by biochar in cold waterlogged paddy fields. Thus, it is imperative to conduct further investigation to elucidate the long-term effects of biochar in soil-crop ecosystems.

Acknowledgments: This research was supported by the National Key Science and Technology Project: Water Pollution Control and Treatment (2014ZX07101-012).

Author Contributions: Linlin Si and Lianghuan Wu conceived and designed the experiments; Linlin Si and Qingxu Ma performed the experiments; Linlin Si and Yinan Xie analyzed the data; and Linlin Si wrote the paper.

Conflicts of Interest: The authors declare no conflict of interest.

\section{References}

1. Xiong, Y.; Xu, X.; Zhang, Z.; Wang, J.; Yuan, J.; Liu, G.; Xu, C.; Mao, C. Influences of combing ridge and no-tillage on rice yield and soil temperature and distribution of aggregate in cold waterlogged field. Trans. Chin. Soc. Agric. Eng. 2014, 30, 157-164.

2. Xie, K.; Xu, P.; Yang, S.; Lu, Y.; Jiang, R.; Gu, W.; Li, W.; Sun, L. Effects of supplementary composts on microbial communities and rice productivity in cold water paddy fields. J. Microbiol. Biotechnol. 2015, 25, 569-578. [CrossRef] [PubMed]

3. Qiu, S.; Wang, M.K.; Wang, F.; Chen, J.; Li, X.; Li, Q.; Lin, C.; Lin, X. Effects of open drainage ditch design on bacterial and fungal communities of cold waterlogged paddy soils. Braz. J. Microbiol. 2013, 44, 983-991. [CrossRef] [PubMed]

4. Sahrawat, K.L. Organic matter accumulation in submerged soils. Adv. Agron. 2003, 81, 169-201.

5. Muthayya, S.; Sugimoto, J.D.; Montgomery, S.; Maberly, G.F. An overview of global rice production, supply, trade, and consumption. Ann. N. Y. Acad. Sci. 2014, 1324, 7-14. [CrossRef] [PubMed]

6. Muhammad, S.; Faqir, A.; Sher, M.; Javed, M.A.; Waqar, M.Q.; Ali, M.A. Efficacy of different chemicals for the management of bacterial leaf blight of rice (Oryza sativa L.) at various locations of adaptive research zone Sheikhupura. Pak. J. Phytopathol. 2016, 28, 223-230.

7. China Statistical Yearbook. Available online: http://www.stats.gov.cn/tjsj/ndsj/2017/indexch.htm (accessed on 8 January 2018).

8. Yuan, L. Development of hybrid rice to ensure food security. Rice Sci. 2014, 21, 1-2. [CrossRef]

9. Davidson, D.J.; Andrews, J.; Pauly, D. The effort factor: Evaluating the increasing marginal impact of resource extraction over time. Glob. Environ. Chang. 2014, 25, 63-68. [CrossRef]

10. Wang, M.; Ma, L.; Strokal, M.; Chu, Y.; Kroeze, C. Exploring nutrient management options to increase nitrogen and phosphorus use efficiencies in food production of China. Agric. Syst. 2017. [CrossRef]

11. Ma, L.; Feng, S.; Reidsma, P.; Qu, F.; Heerink, N. Identifying entry points to improve fertilizer use efficiency in Taihu Basin, China. Land Use Policy 2014, 37, 52-59. [CrossRef]

12. Bellarby, J.; Siciliano, G.; Smith, L.; Xin, L.; Zhou, J.; Liu, K.; Jie, L.; Meng, F.; Inman, A.; Rahn, C. Strategies for sustainable nutrient management: Insights from a mixed natural and social science analysis of Chinese crop production systems. Environ. Dev. 2017, 21, 52-65. [CrossRef]

13. Yang, H.; Feng, J.; Zhai, S.; Dai, Y.; Xu, M.; Wu, J.; Shen, M.; Bian, X.; Koide, R.T.; Liu, J. Long-term ditch-buried straw return alters soil water potential, temperature, and microbial communities in a rice-wheat rotation system. Soil Tillage Res. 2016, 163, 21-31. [CrossRef]

14. Lou, Y.; Ren, L.; Li, Z.; Zhang, T.; Inubushi, K. Effect of rice residues on carbon dioxide and nitrous oxide emissions from a paddy soil of subtropical China. Water Air Soil Pollut. 2007, 178, 157-168. [CrossRef]

15. Zhao, X.; Wang, J.; Wang, S.; Xing, G. Successive straw biochar application as a strategy to sequester carbon and improve fertility: A pot experiment with two rice/wheat rotations in paddy soil. Plant Soil 2014, 378, 279-294. [CrossRef] 
16. Lehmann, J.; Joseph, S. Biochar for environmental management: An introduction. In Biochar for Environmental Management: Science, Technology and Implementation, 2nd ed.; Lehmann, J., Joseph, S., Eds.; Earthscan: London, UK, 2015; pp. 1-15.

17. Lehmann, J.; Rillig, M.C.; Thies, J.; Masiello, C.A.; Hockaday, W.C.; Crowley, D. Biochar effects on soil biota-A review. Soil Biol. Biochem. 2011, 43, 1812-1836. [CrossRef]

18. Burrell, L.D.; Zehetner, F.; Rampazzo, N.; Wimmer, B.; Soja, G. Long-term effects of biochar on soil physical properties. Geoderma 2016, 282, 96-102. [CrossRef]

19. Basso, A.S.; Miguez, F.E.; Laird, D.A.; Horton, R.; Westgate, M. Assessing potential of biochar for increasing water-holding capacity of sandy soils. GCB Bioenergy 2013, 5, 132-143. [CrossRef]

20. Abujabhah, I.S.; Bound, S.A.; Doyle, R.; Bowman, J.P. Effects of biochar and compost amendments on soil physico-chemical properties and the total community within a temperate agricultural soil. Appl. Soil Ecol. 2016, 98, 243-253. [CrossRef]

21. Głąb, T.; Palmowska, J.; Zaleski, T.; Gondek, K. Effect of biochar application on soil hydrological properties and physical quality of sandy soil. Geoderma 2016, 281, 11-20. [CrossRef]

22. Mukherjee, A.; Lal, R. The biochar dilemma. Soil Res. 2014, 52, 217-230. [CrossRef]

23. Wu, W.; Yang, M.; Feng, Q.; Mcgrouther, K.; Wang, H.; Lu, H.; Chen, Y. Chemical characterization of rice straw-derived biochar for soil amendment. Biomass Bioenergy 2012, 47, 268-276. [CrossRef]

24. Kuppusamy, S.; Thavamani, P.; Megharaj, M.; Venkateswarlu, K.; Naidu, R. Agronomic and remedial benefits and risks of applying biochar to soil: Current knowledge and future research directions. Environ. Int. 2016, 87, 1-12. [CrossRef] [PubMed]

25. Dong, D.; Feng, Q.; Mcgrouther, K.; Yang, M.; Wang, H.; Wu, W. Effects of biochar amendment on rice growth and nitrogen retention in a waterlogged paddy field. J. Soils Sediments 2015, 15, 153-162. [CrossRef]

26. Cui, Y.F.; Meng, J.; Wang, Q.X.; Zhang, W.M.; Cheng, X.Y.; Chen, W.F. Effects of straw and biochar addition on soil nitrogen, carbon, and super rice yield in cold waterlogged paddy soils of North China. J. Integr. Agric. 2017, 16, 1064-1074. [CrossRef]

27. Glaser, B.; Wiedner, K.; Seelig, S.; Schmidt, H.; Gerber, H. Biochar organic fertilizers from natural resources as substitute for mineral fertilizers. Agron. Sustain. Dev. 2015, 35, 667-678. [CrossRef]

28. Enders, A.; Lehmann, J. Comparison of wet-digestion and dry-ashing methods for total elemental analysis of biochar. Commun. Soil Sci. Plant Anal. 2012, 43, 1042-1052. [CrossRef]

29. Zhejiang Weather. Available online: http:// zj.weather.com.cn (accessed on 1 February 2018).

30. Cabangon, R.J.; Tuong, T.P.; Castillo, E.G.; Bao, L.X.; Lu, G.; Wang, G.; Cui, Y.; Bouman, B.A.; Li, Y.; Chen, C. Effect of irrigation method and $\mathrm{N}$-fertilizer management on rice yield, water productivity and nutrient-use efficiencies in typical lowland rice conditions in China. Paddy Water Environ. 2004, 2, 195-206. [CrossRef]

31. Smith, K.A.; Mullins, C.E. Soil and Environmental Analysis: Physical Methods, 2nd ed.; Marcel Dekker, Inc.: New York, NY, USA, 2000; pp. 1-64.

32. Chapman, H.D. Cation Exchange Capacity. In Methods of Soil Analysis; ASA: Madison, WI, USA, 1965; pp. 891-901.

33. Aparicio, V.C.; De Gerónimo, E.; Marino, D.; Primost, J.; Carriquiriborde, P.; Costa, J.L. Environmental fate of glyphosate and aminomethylphosphonic acid in surface waters and soil of agricultural basins. Chemosphere 2013, 93, 1866-1873. [CrossRef] [PubMed]

34. Dai, Z.; Liu, Y.; Wang, X.; Zhao, D. Changes in pH, CEC and exchangeable acidity of some forest soils in southern China during the last 32-35 years. Water Air Soil Pollut. 1998, 108, 377-390. [CrossRef]

35. Lu, R.K. Methods of Soil and Agro-Chemical Analysis; China Agricultural Science and Technology Press: Beijing, China, 2000; pp. 146-165.

36. Swift, R.S. Organic matter characterization. In Methods of Soil Analysis; Sparks, D.L., Ed.; Soil Science Society of America: Madison, WI, USA, 1996; pp. 1011-1069.

37. Bray, R.H.; Kurtz, L.T. Determination of total, organic, and available forms of phosphorus in soils. Soil Sci. 1945, 59, 39-46. [CrossRef]

38. Zhang, T.; Li, S.; Sun, X.; Zhang, Y.; Gong, X.; Fu, Y.; Jia, L. The earthworm Eisenia fetida can help desalinate a coastal saline soil in Tianjin, North China. PLoS ONE 2015, 10, e144709. [CrossRef] [PubMed]

39. Thomas, R.L.; Sheard, R.W.; Moyer, J.R. Comparison of conventional and automated procedures for nitrogen, phosphorus, and potassium analysis of plant material using a single digestion. Agron. J. 1967, 59, $240-243$. [CrossRef] 
40. Zhao, B.; Chen, J.; Zhang, J.; Xin, X.; Hao, X. How different long-term fertilization strategies influence crop yield and soil properties in a maize field in the North China Plain. J. Plant Nutr. Soil Sci. 2013, 176, 99-109. [CrossRef]

41. Peng, X.; Ye, L.L.; Wang, C.H.; Zhou, H.; Sun, B. Temperature-and duration-dependent rice straw-derived biochar: Characteristics and its effects on soil properties of an Ultisol in southern China. Soil Tillage Res. 2011, 112, 159-166. [CrossRef]

42. Lu, K.; Yang, X.; Shen, J.; Robinson, B.; Huang, H.; Liu, D.; Bolan, N.; Pei, J.; Wang, H. Effect of bamboo and rice straw biochars on the bioavailability of $\mathrm{Cd}, \mathrm{Cu}, \mathrm{Pb}$ and $\mathrm{Zn}$ to Sedum plumbizincicola. Agric. Ecosyst. Environ. 2014, 191, 124-132. [CrossRef]

43. Chintala, R.; Mollinedo, J.; Schumacher, T.E.; Malo, D.D.; Julson, J.L. Effect of biochar on chemical properties of acidic soil. Arch. Agron. Soil Sci. 2014, 60, 393-404. [CrossRef]

44. Yuan, J.; $\mathrm{Xu}, \mathrm{R}$. The amelioration effects of low temperature biochar generated from nine crop residues on an acidic Ultisol. Soil Use Manag. 2015, 27, 110-115. [CrossRef]

45. He, X.; Zhang, S.; She, D.; Geng, Z.; Gao, H. Effects of biochar on soil and fertilizer and future research. Chin. Agric. Sci. Bull. 2011, 27, 16-25.

46. Atkinson, C.J.; Fitzgerald, J.D.; Hipps, N.A. Potential mechanisms for achieving agricultural benefits from biochar application to temperate soils: A review. Plant Soil 2010, 337, 1-18. [CrossRef]

47. Novak, J.M.; Busscher, W.J.; Laird, D.L.; Ahmedna, M.; Watts, D.W.; Niandou, M.A.S. Impact of biochar amendment on fertility of a southeastern Coastal Plain soil. Soil Sci. 2009, 174, 105-112. [CrossRef]

48. Nguyen, C.Q.; Guppy, C.; Moody, P.; Gilkes, R.J.; Prakongkep, N. Effect of P and Si amendment on the charge characteristics and management of a Geric soil. In Proceedings of the 19th World Congress of Soil Science: Soil Solutions for a Changing World, Brisbane, Australia, 1-6 August 2010.

49. Li, M.; Liu, M.; Li, Z.; Jiang, C.; Wu, M. Soil N transformation and microbial community structure as affected by adding biochar to a paddy soil of subtropical China. J. Integr. Agric. 2016, 15, 209-219. [CrossRef]

50. Zhang, A.; Bian, R.; Pan, G.; Cui, L.; Hussain, Q.; Li, L.; Zheng, J.; Zheng, J.; Zhang, X.; Han, X. Effects of biochar amendment on soil quality, crop yield and greenhouse gas emission in a Chinese rice paddy: A field study of 2 consecutive rice growing cycles. Field Crop. Res. 2012, 127, 153-160. [CrossRef]

51. Lin, C.; Li, Q.; Wang, F.; He, C.; Zhong, S.; Li, Y.; Lin, X. Effects of phosphorus fertilizer on phosphorus content, photosynthesis characters and yield of rice in cold waterlogged paddy field. J. Trop. Subtrop. Bot. 2016, 24, 553-558.

52. Ierna, A.; Mauro, R.P.; Mauromicale, G. Improved yield and nutrient efficiency in two globe artichoke genotypes by balancing nitrogen and phosphorus supply. Agron. Sustain. Dev. 2012, 32, 773-780. [CrossRef]

53. Qiu, S.; He, P.; Zhao, S.; Li, W.; Xie, J.; Hou, Y.; Grant, C.A.; Zhou, W.; Jin, J. Impact of nitrogen rate on maize yield and nitrogen use efficiencies in northeast China. Agron. J. 2014, 107, 305-313. [CrossRef]

54. Zhu, X.; Li, C.; Jiang, Z.; Huang, L.; Feng, C.; Guo, W.; Peng, Y. Responses of phosphorus use efficiency, grain yield, and quality to phosphorus application amount of weak-gluten wheat. J. Integr. Agric. 2012, 11, 1103-1110. [CrossRef]

55. Islam, A.; Muttaleb, A. Effect of potassium fertilization on yield and potassium nutrition of Boro rice in a wetland ecosystem of Bangladesh. Arch. Agron. Soil Sci. 2016, 62, 1530-1540. [CrossRef]

56. Yang, X.; Liu, J.; Wang, W.; Ye, Z.; Luo, A. Potassium internal use efficiency relative to growth vigor, potassium distribution, and carbohydrate allocation in rice genotypes. J. Plant Nutr. 2004, 27, 837-852. [CrossRef]

57. Biederman, L.A.; Harpole, W.S. Biochar and its effects on plant productivity and nutrient cycling: A meta-analysis. GCB Bioenergy 2013, 5, 202-214. [CrossRef]

58. Liu, Y.; Lu, H.; Yang, S.; Wang, Y. Impacts of biochar addition on rice yield and soil properties in a cold waterlogged paddy for two crop seasons. Field Crop. Res. 2016, 191, 161-167. [CrossRef]

59. Jeffery, S.; Verheijen, F.G.; Van Der Velde, M.; Bastos, A.C. A quantitative review of the effects of biochar application to soils on crop productivity using meta-analysis. Agric. Ecosyst. Environ. 2011, 144, 175-187. [CrossRef]

60. Nguyen, D.H.; Scheer, C.; Rowlings, D.W.; Grace, P.R. Rice husk biochar and crop residue amendment in subtropical cropping soils: Effect on biomass production, nitrogen use efficiency and greenhouse gas emissions. Biol. Fertil. Soils 2016, 52, 261-270. [CrossRef] 
61. Solaiman, Z.M.; Blackwell, P.; Abbott, L.K.; Storer, P.; Krull, E.; Singh, B.; Joseph, S. Direct and residual effect of biochar application on mycorrhizal root colonisation, growth and nutrition of wheat. Soil Res. 2010, 48, 546-554. [CrossRef]

62. Van Zwieten, L.; Kimber, S.; Morris, S.; Chan, K.Y.; Downie, A.; Rust, J.; Joseph, S.; Cowie, A. Effects of biochar from slow pyrolysis of papermill waste on agronomic performance and soil fertility. Plant Soil 2010, 327, 235-246. [CrossRef]

63. Chen, X.; He, X.; Geng, Z.; Zhang, W.; Gao, H. Effects of biochar on selected soil chemical properties and on wheat and millet yield. Acta Ecol. Sin. 2013, 33, 6534-6542. [CrossRef]

64. Glaser, B.; Lehmann, J.; Zech, W. Ameliorating physical and chemical properties of highly weathered soils in the tropics with charcoal-a review. Biol. Fertil. Soils 2002, 35, 219-230. [CrossRef]

65. Liang, F.; Li, G.; Lin, Q.; Zhao, X. Crop yield and soil properties in the first 3 years after biochar application to a calcareous soil. J. Integr. Agric. 2014, 13, 525-532. [CrossRef]

66. Graber, E.R.; Harel, Y.M.; Kolton, M.; Cytryn, E.; Silber, A.; David, D.R.; Tsechansky, L.; Borenshtein, M.; Elad, Y. Biochar impact on development and productivity of pepper and tomato grown in fertigated soilless media. Plant Soil 2010, 337, 481-496. [CrossRef]

67. Laird, D.A.; Novak, J.M.; Collins, H.P.; Ippolito, J.A.; Karlen, D.L.; Lentz, R.D.; Sistani, K.R.; Spokas, K.; Pelt, R.S.V. Multi-year and multi-location soil quality and crop biomass yield responses to hardwood fast pyrolysis biochar. Geoderma 2017, 289, 46-53. [CrossRef]

68. Chan, K.Y.; Xu, Z. Biochar: Nutrient properties and their enhancement. In Biochar for Environmental Management: Science and Technology; Lehmann, J., Joseph, S., Eds.; Earthscan: London, UK, 2009; pp. 67-84.

69. Chen, Y.; Zhang, M.; Liu, X.; Dai, G.; Hou, S. Effects of biochar on chlorophyll fluorescence at full heading stage and yield components of rice. Crops 2016, 94-98.

70. Sohi, S.; Lopez-Capel, E.; Krull, E.; Bol, R. Biochar, Climate Change and Soil: A Review to Guide Future Research; CSIRO Land and Water Science Report 05/09; CSIRO: Canberra, Australia, 2009.

71. Major, J.; Rondon, M.; Molina, D.; Riha, S.J.; Lehmann, J. Maize yield and nutrition during 4 years after biochar application to a Colombian savanna oxisol. Plant Soil 2010, 333, 117-128. [CrossRef]

(C) 2018 by the authors. Licensee MDPI, Basel, Switzerland. This article is an open access article distributed under the terms and conditions of the Creative Commons Attribution (CC BY) license (http:/ / creativecommons.org/licenses/by/4.0/). 